\title{
Hydrologic Changes After \\ Logging in Two Small \\ Oregon Coastal Watersheds
}

GEOLOGICAL SURVEY WATER-SUPPLY PAPER 2037

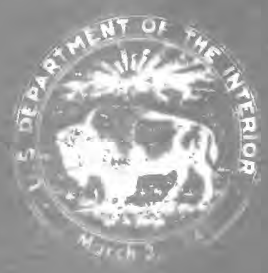




\section{Hydrologic Changes After Logging in Two Small}

Oregon Coastal Watersheds By D. D. HARRIS

GEOLOGICAL SURVEY WATER-SUPPLY PAPER 2037

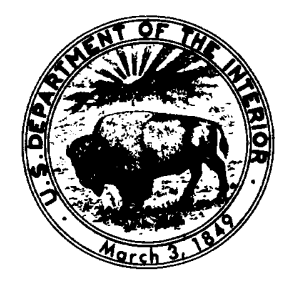




\section{UNITED STATES DEPARTMENT OF THE INTERIOR}

THOMAS S. KLEPPE, Secretary

\section{GEOLOGICAL SURVEY}

V. E. McKelvey, Director

Library of Congress catalog-card No. 76-52571

For sale by the Superintendent of Documents, U. S. Government Printing Office Washington, D. C. 20402

Stock Number 024-001-02938-3 


\section{CONTENTS}

Definition of terms

Conversion factors

Abstract _...

Introduction _....... 1

Data collection _............ 2

Analysis and interpretation of the data

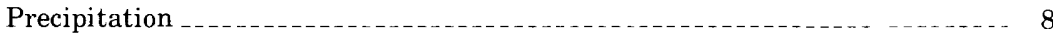

Streamflow _..... 10

Annual runoff ......... 10

High flow -

Low flow

Sediment transport

Sediment concentration

Sediment yield _._._._._. 22

Particle-size distribution .................. 24

Water temperature ........ 24

Summary _._.

Selected references _..... 30

\section{ILLUSTRATIONS}

FIGURE 1. Map showing locations of study watersheds in Alsea River basin 3

2. Photograph showing Needle Branch after logging and burning, November $1966 \ldots$

3. Photographs showing regrowth of vegetation on Needle Branch after logging

4. Photograph showing logged area in Deer Creek watershed, 1966 .. 6

5-16. Graphs showing:

5. Monthly precipitation at Tidewater, 1972 and $1973 \ldots \ldots \ldots$

6. Relation of cumulative annual precipitation at Needle Branch and Deer Creek gages to that at Flynn Creek gage ................ 11

7. Monthly runoff of Flynn Creek, 1972 and 1973

8. Relation of annual runoff of Needle Branch and of Deer Creek to that of Flynn Creek

9. Relation of cumulative annual runoff of Needle Branch and of Deer Creek to that of Flynn Creek

10. Relation of peak flow of Needle Branch and of Deer Creek to that of Flynn Creek

11. Relation of 3-day high-flow runoff of Needle Branch and of Deer Creek to that of Flynn Creek

12. Relation of low flow of Needle Branch and of Deer Creek to that of Flynn Creek 
Figure

13. Relation of annual discharge-weighted mean sediment concentrations of Needle Branch and of Deer Creek to those of Flynn Creek

14. Relation of annual sediment yields of Needle Branch and of Deer Creek watersheds to those of Flynn Creek watershed

15. Relation of cumulative annual sediment yields of Needle Branch and of Deer Creek watersheds to those of Flynn Creek watershed

16. Relation of maximum monthly water temperatures (AprilOctober) of Needle Branch and of Deer Creek to those of Flynn Creek

\section{TABLES}

TABLE 1. Prediction equations derived from analyses of prelogging data $\begin{array}{r}\text { Page } \\ -\ldots-1\end{array}$

2. Annual precipitation ............... 9

3. Annual runoff

4. Peak discharges and runoffs for all peaks greater than $50\left(\mathrm{ft}^{3} / \mathrm{s}\right) / \mathrm{mi}^{2}$ on Flynn Creek and concurrent peaks on Needle Branch and Deer Creek _................... 16

5. Three-day high-flow runoff for Flynn Creek, Needle Branch, and Deer Creek

6. Minimum daily August-September flows of Flynn Creek and concurrent flows of Needle Branch and Deer Creek _. 20

7. Maximum mean daily sediment concentrations _............... 22

8. Annual sediment yields of the three study watersheds ............. 24

9. Approximate size distribution of sediment sampled at the weirs before, during, and after logging

10. Water temperatures before and after logging _..._._.

11. Summary of postlogging values and changes in hydrologic characteris-

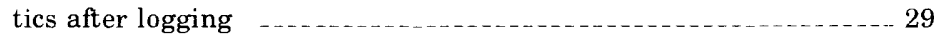

\section{DEFINITION OF TERMS}

Cubic feet per second $\left(\mathrm{ft}^{3} / \mathrm{s}\right)$ is a unit expressing rate of discharge. One cubic foot per second is equal to the discharge of a stream whose channel is 1 square foot in cross-sectional area and whose velocity is 1 foot per second.

Cubic feet per second per square mile $\left[\left(\mathrm{ft}^{3} / \mathrm{s}\right) / \mathrm{mi}^{2}\right]$ is the number of cubic feet of water flowing per second from each square mile of area drained, assuming that the runoff is distributed uniformly in time and area.

Discharge-weighted mean sediment concentration is the theoretical sediment concentration if all the water and sediment passing a section during a time interval were mixed; concentrations are expressed in milligrams per litre $(\mathrm{mg} / \mathrm{l})$.

Gaging station is a particular site on a stream where systematic observations of gage height and discharge are obtained. 
Particle size is the diameter, in millimetres $(\mathrm{mm})$, of suspended sediment or bed material, determined by sieve and sedimentation methods.

Particle-size classification agrees closely with recommendations made by the American Geophysical Union Subcommittee on Sediment Terminology (Lane, 1947, p. 937). The classification is as follows:

Clay: Smaller than $0.004 \mathrm{~mm}$.

Silt: Between 0.004 and $0.062 \mathrm{~mm}$.

Sand: Between 0.062 and $2.0 \mathrm{~mm}$.

Gravel: Between 2.0 and $64.0 \mathrm{~mm}$.

Milligrams per litre $(\mathrm{mg} / \mathrm{l})$ for sediment is based on the weight of sediment per litre of water-sediment mixture.

Prediction limits are lines about the regression curves for a selected significance level within the range of previously experienced values. They are computed from the equation:

$$
\cdot \underset{L}{U}\}= \pm t[(1+\gamma) / 2](n-2)^{S p}
$$

where

$t$ is a value for statistical " $t$ " distribution table (Dixon and Massey, 1957),

$\gamma$ is a selected confidence level (95 percent),

$n$ is the number of previously experienced values.

$S p$ is a standard error of prediction, and

$U$ and $L$ are the upper and lower prediction limits about the curve.

Runoff is that part of the precipitation that appears in surface streams. Runoff in inches (in.) shows the depth to which the drainage area would be covered if all the runoff for a given time period were uniformly distributed.

Sediment is solid material that originates mostly from disintegrated rocks and is transported by, suspended in, or deposited from water; it includes chemical and biochemical precipitates and decomposed organic material such as humus. The quantity, characteristics, and cause of occurrence of sediment in streams are influenced by environmental factors. Some major factors are: degree of exposure to flowing water, degree and length of slope, soil and rock-material characteristics, land usage, and quantity and intensity of precipitation.

Sediment load is the total weight of sediment being moved by the stream or the quantity of sediment that is transported in a given length of time.

Standard error of estimate $(\mathrm{Se})$ is a measure of the variation of points about the regression line. Lines drawn a vertical distance of one standard error of estimate above and below the line of regression will encompass about two-thirds of the defining points.

Standard error of prediction ( $S p$ ) is made up of three parts: the error of the mean, the error of the slope of the line, and the standard error of estimate. It is computed as

$$
S p=\operatorname{Se} \sqrt{1+\frac{1}{n}+\frac{(X-\bar{X})^{2}}{\Sigma x^{2}}}
$$

where

$\mathrm{Se}$ is standard error of estimate.

$n$ is number of items in the sample,

$X$ is any single value,

$\bar{X}$ is the mean value for the period 1959-65, and

$\Sigma x^{2}$ is the summation of the squared deviation of $X$ from $\bar{X}$ for the period 1959-65. 
Suspended sediment is the sediment that at any given time is maintained in suspension by the upward components of turbulent currents or that exists in suspension as a colloid.

Water year is the 12-month period, October 1 through September 30 . The water year is designated by the calendar year in which it ends and which includes 9 of the 12 months. Thus, the year ending September 30, 1959, is called the 1959 water year.

\section{CONVERSION FACTORS}

Factors for converting English units to metric units are shown to four significant figures; however, in the text the metric equivalents are shown only to the number of significant figures consistent with the values for the English units.

\begin{tabular}{|c|c|c|}
\hline Multiply English units & By & To obtain metric units \\
\hline \multicolumn{3}{|l|}{ Length } \\
\hline inches (in.) & 25.4 & millimetres (mm) \\
\hline feet $(\mathrm{ft}) \ldots$ & .3048 & metres $(\mathrm{m})$ \\
\hline miles (mi) & 1.609 & kilometres $(\mathrm{km})$ \\
\hline \multicolumn{3}{|l|}{ Area } \\
\hline acres & .004047 & square kilometres $\left(\mathrm{km}^{2}\right)$ \\
\hline square miles $\left(\mathrm{mi}^{2}\right)$ & 2.590 & square kilometres $\left(\mathrm{km}^{2}\right)$ \\
\hline \multicolumn{3}{|l|}{ Volume } \\
\hline cubic feet $\left(\mathrm{ft}^{3}\right)$ & .02832 & cubic metres $\left(\mathrm{m}^{3}\right)$ \\
\hline acre-feet (acre-ft) & .001233 & cubic hectometres $\left(\mathrm{hm}^{3}\right)$ \\
\hline \multicolumn{3}{|l|}{ Flow } \\
\hline $\begin{array}{l}\text { cubic feet per second }\left(\mathrm{ft}^{3} / \mathrm{s}\right) \\
\text { cubic feet per second per square }\end{array}$ & .02832 & $\begin{array}{l}\text { cubic metres per second }\left(\mathrm{m}^{3} / \mathrm{s}\right) \\
\text { cubic metres per second per square }\end{array}$ \\
\hline mile $\left[\left(\mathrm{ft}^{3} / \mathrm{s}\right) / \mathrm{mi}^{2}\right]$ & .01093 & kilometre $\left[\left(\mathrm{m}^{3} / \mathrm{s}\right) / \mathrm{km}^{2}\right]$ \\
\hline \multicolumn{3}{|l|}{ Mass } \\
\hline 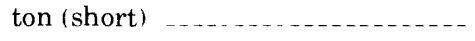 & .9072 & tonne $(\mathrm{t})$ \\
\hline tons per square mile (tons $/ \mathrm{mi}^{2}$ ) & .3502 & tonnes per square kilometre $\left(\mathrm{t} / \mathrm{km}^{2}\right)$ \\
\hline
\end{tabular}




\title{
HYDROLOGIC CHANGES AFTER LOGGING IN TWO SMALL OREGON COASTAL WATERSHEDS
}

\author{
BY D. D. HARRIS
}

ABSTRACT

\begin{abstract}
Effects of clearcut, cable logging on the hydrologic characteristics of a small coastal stream in Oregon indicate an average 181-percent increase in sediment yield over a 7-year postlogging period. Annual runoff and high-flow volumes increased 19 and 1.1 inches ( 480 and $28 \mathrm{~mm}$ ), respectively, after logging in the watershed. Clearcutting in small, spaced patches in another watershed resulted in some increase in water and sediment yields, but the increase was not statistically significant. Average monthly April-October maximum water temperatures increased significantly in the principal stream of both the clearcut and "patch-cut" watersheds. Hydrologic characteristics of both streams generally appear to be returning to prelogging conditions (1973).
\end{abstract}

\section{INTRODUCTION}

The study described in this report is part of a large interdisciplinary research study started in 1957 by the Oregon Governor's Committee on Natural Resources to examine the impact of two different logging practices on stream environment. The Oregon State University Department of Fisheries and Wildlife and Oregon State Game Commission (now Oregon Department of Fish and Wildlife) studied the effects of logging on fish habitat, particularly in relation to salmon spawning. The School of Forestry at Oregon State University made some special detailed hydrologic studies on the effects of logging. The U.S. Geological Survey studied the integrated effects of logging on the hydrologic characteristics of streams. Other participants in the study were the U.S. Forest Service, U.S. Soil Conservation Service, and Georgia-Pacific Corporation.

To investigate the effects of logging, three small watersheds in the Alsea River basin on the west slope of the Oregon Coast Range were chosen for the study. Needle Branch watershed was entirely clearcut and burned, Deer Creek watershed was clearcut in patches of various sizes, and Flynn Creek watershed was left uncut and was used as a control for comparing prelogging and postlogging characteristics. All logging was done by the high-line cable method. Hydrologic data were collected on all three streams for 15 years beginning in the 1959 water year; the data cover 7 years before logging (1959-65 water 
years), 1 year during logging (1966 water year), and 7 years after logging (1967-73 water years). The purpose of this report is to present the results of the evaluation of changes in streamflow, sedimentation, and water temperatures after logging.

The three watersheds were selected for the study because they have the same general geographic location, direction of exposure, and elevation. The watersheds are shown on the map in figure 1. Flynn Creek has a drainage area of $0.78 \mathrm{mi}^{2}\left(2.02 \mathrm{~km}^{2}\right)$, or 502 acres. Forest cover is about 70 percent alder and 30 percent Douglas fir. Needle Branch has a drainage area of $0.27 \mathrm{mi}^{2}\left(0.70 \mathrm{~km}^{2}\right)$, or 175 acres. Forest cover was 85 percent alder and maple before cutting. Thirtytwo acres $\left(0.13 \mathrm{~km}^{2}\right)$ in the headwaters had been previously logged in the early 1950's. Deer Creek has a drainage area of $1.17 \mathrm{mi}^{2}(3.03$ $\mathrm{km}^{2}$ ), or 750 acres. Forest cover was about 60 percent Douglas fir and 40 percent alder. Figure 2 shows Needle Branch watershed in 1966 immediately after logging and burning. Figure 3 shows the same area in 1970 and in 1973 after vegetation regrowth had started. Figure 4 shows an area in the Deer Creek watershed soon after logging.

Hydrologic characteristics of the three study watersheds during the prelogging period were described in reports by Williams (1964) and by 'Harris and Williams (1971). Preliminary studies of hydrologic changes after logging on Needle Branch were described in a report by Harris (1973). The effects of the road construction, clearcutting, and slash-burning phases on sediment production of the study watersheds were described in a report by Brown and Krygier (1971).

\section{DATA COLLECTION}

Measurements of precipitation, streamflow, sediment transport, and water temperature near the mouths of the three study streams before, during, and after logging, provided the data needed to evaluate some of the effects of logging. Precipitation data were collected by Oregon State University. All data on streamflow, sediment transport, and water temperature used in this report were collected by the U.S. Geological Survey and published in basic-data reports.

Precipitation data, collected at weighing-type rain gages near each of the three outflow stream-gaging stations, were used to verify that the areal distribution of precipitation did not change noticeably during the study. These data were collected only through February 1968, but they provide sufficient information to check the consistency of the areal precipitation distribution through the first full year after logging. Because the data were collected at the low point in each basin, they probably do not represent average precipitation over the basins.

Streamflow data were collected at standard U.S. Geological Survey gaging stations on each of the three study streams during the entire 


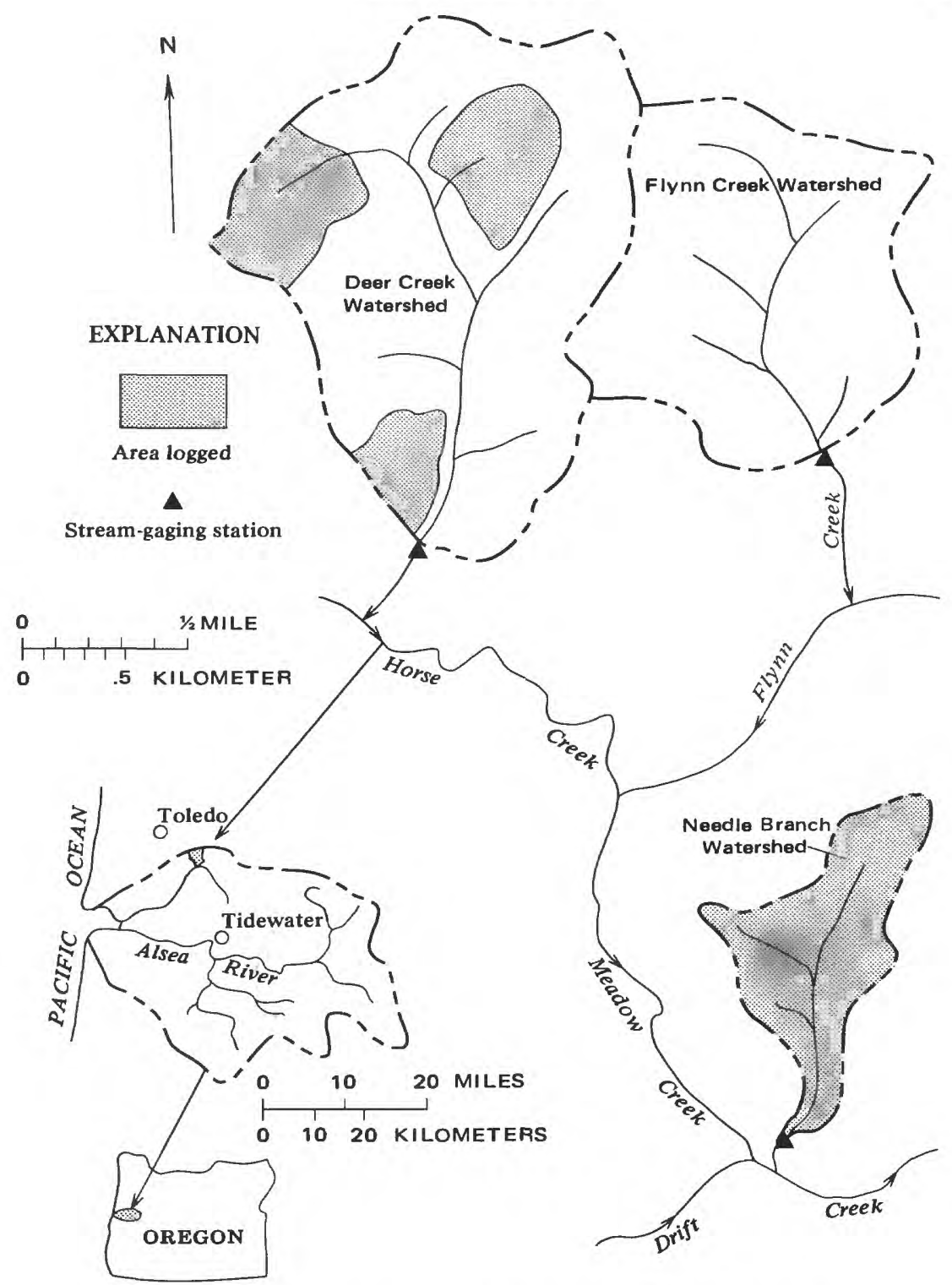

Figure 1.-Locations of study watersheds in Alsea River basin, Oregon.

15 years of the study. The stage-control structure for each station is a concrete V-notch weir. Discharges at the gaging stations were determined from stage-discharge relations defined by a series of discharge measurements. High- and medium-flow discharge measurements were made using either the standard Price or pygmy current meter; 


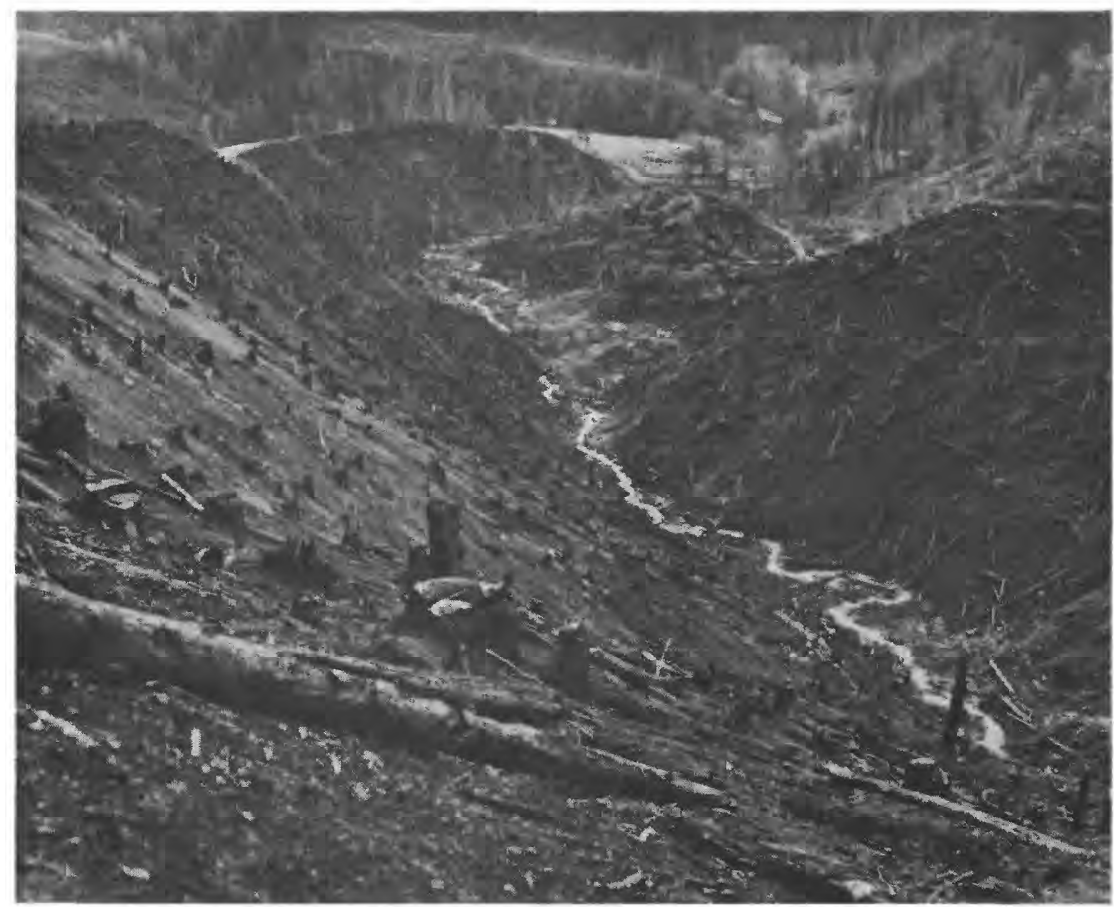

FigURE 2.-Needle Branch immediately after logging and burning, November 1966. Photograph courtesy of U.S. Bureau of Land Management.

low-flow measurements were made volumetrically. On Flynn and Deer Creeks, volumetric measurements were made by timing the filling of a concrete box located immediately downstream from the weirs; on Needle Branch they were usually made by timing the filling of a metal container of known volume held below the weir. Each discharge measurement was plotted to the concurrent gage height. Stage-discharge relations were developed from the measurements for each site and were used to obtain the discharge data for the analyses. Records were generally considered to be good to excellent for all three stations.

Sediment transport was measured at each of the three streamgaging stations. The sediment-load data presented in this report are composed of two parts: (1) that computed from sediment-transport data obtained with a U.S. DH-48 sediment sampler and published in U.S. Geological Survey basic-data reports, and (2) that which was determined from sediment deposits in the backwater area behind the 

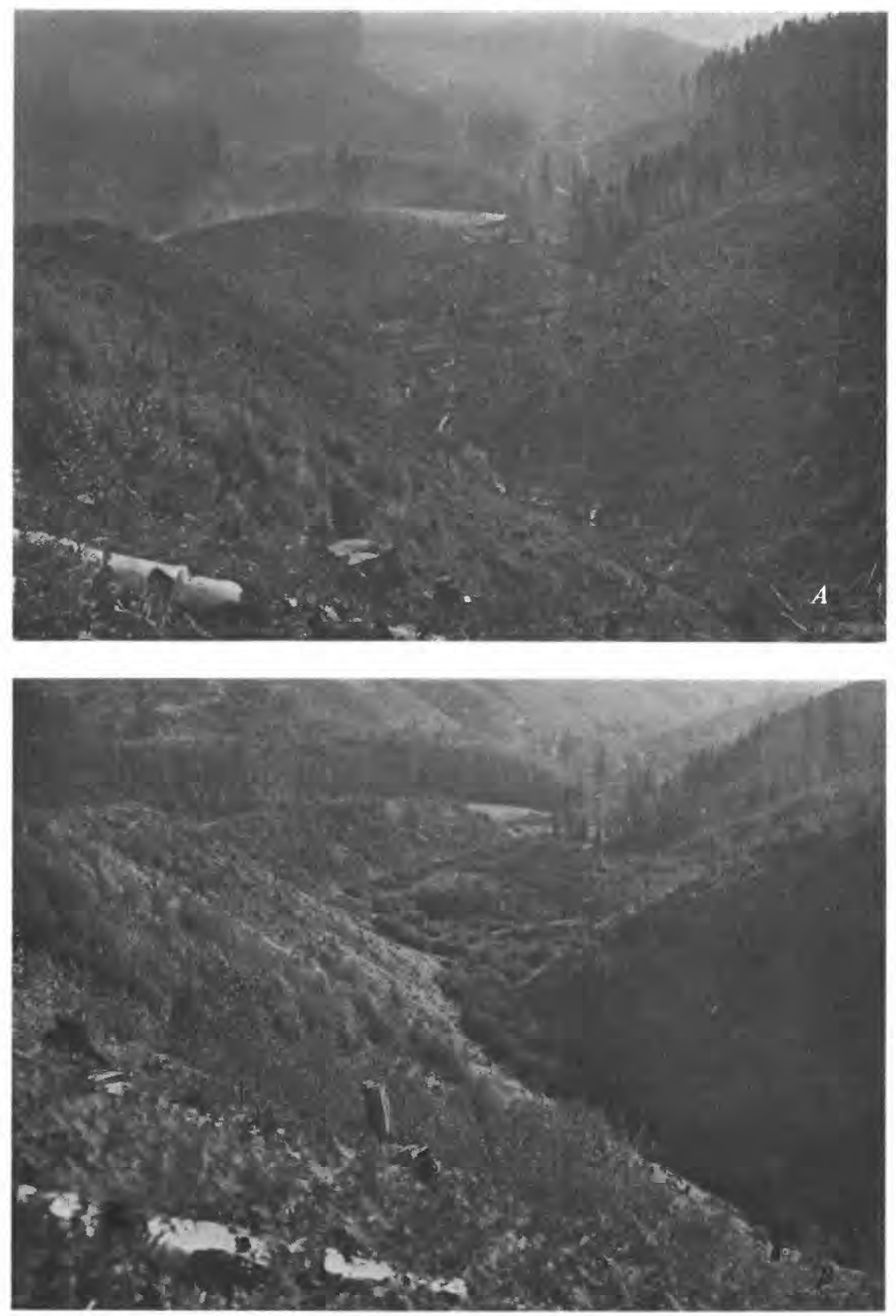

Figure 3.- Regrowth of vegetation on Needle Branch after logging. A, October 1970. $B$, October 1973. 


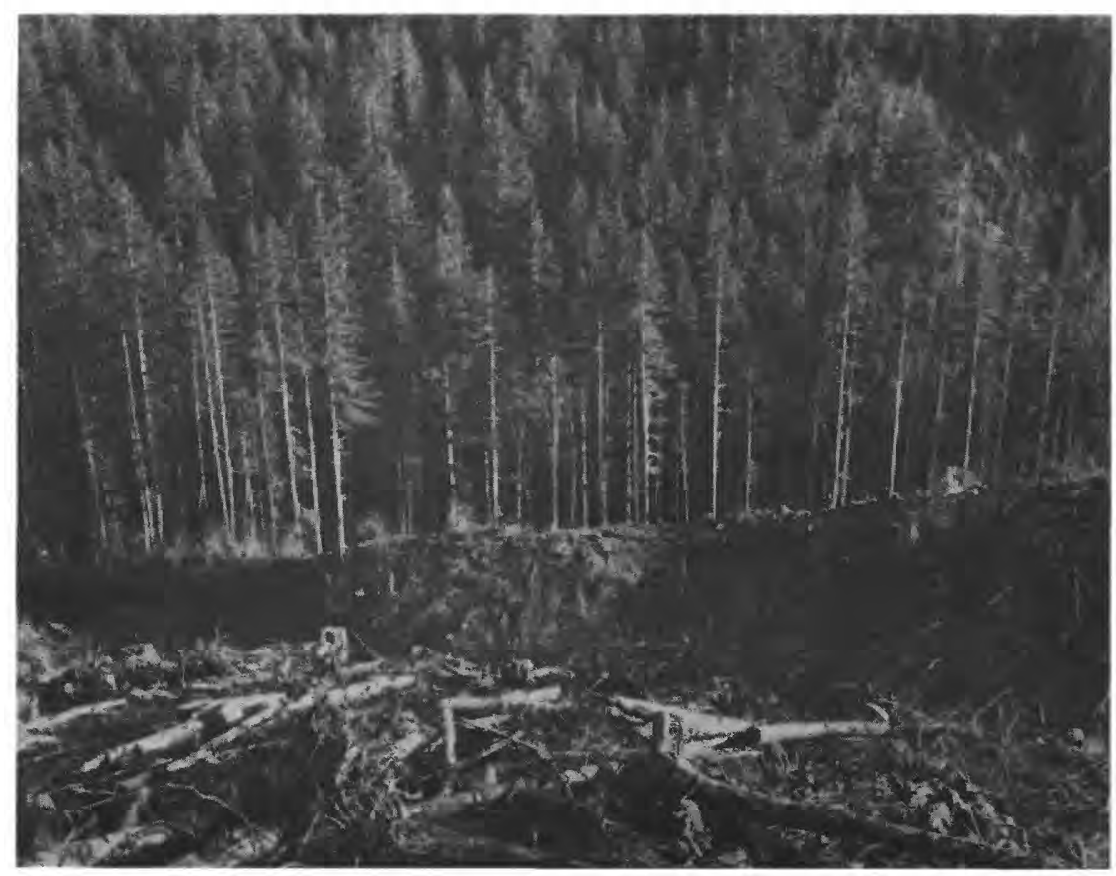

Figure 4.-Logged area in Deer Creek watershed, 1966. Photograph courtesy of U.S. Bureau of Land Management.

gaging-station weir pools. For the purpose of this report, the combination of the two parts is considered to be an estimate of the total load.

The major part of the load was sampled at the three sites and computed by methods outlined in the U.S. Geological Survey watersupply paper series "Quality of Surface Waters of the United States" and in the reports of the U.S. Inter-Agency Committee on Water Resources (1957a, 1957b, 1959, 1961, 1963). During the 1959-61 water years, the suspended-sediment load was sampled with $\mathrm{DH}-48$ samplers at footbridges several hundred feet upstream from the gaging stations. Beginning with the 1962 water year, sampling was done on the concrete control weirs. Samples were collected daily and at more frequent intervals during periods of high flow. In the sampling process, the nozzle of the DH-48 sampler traversed the entire depth of the stream-from water surface to the crest of the weir. Some particles that normally travel as bedload were caught by the samplers; therefore, in this report the loads computed from these samples are called "sampled loads" instead of the commonly used term "suspended loads." To obtain equivalent records for the entire calibration period, adjustments were made to the sediment-load records for the 
1959-61 water years on the basis of comparison samples obtained at the two sites on each stream during the 1961 water year.

The part of the sediment load trapped in the weir pools was determined by cross-section surveys at the end of each water year, beginning in 1962. The volume of fill or scour was computed by the method of average-end areas.

The annual yields computed from sediment-sample data were adjusted to compensate for the amount of sediment filling in or scouring from the weir pools. The amount of net fill occurring during a year was added to that year's sediment load because the material presumably would have passed the gaging station had the weir not been there, whereas the amount equivalent to net scour was subtracted from the load because this material passed over the weir but probably did not come off the watershed during the year it was measured. The amount of the adjustments for fill or scour during the postlogging period averaged less than 4 percent of the annual sampled load on Flynn Creek, less than 1 percent on Needle Branch, and less than 2 percent on Deer Creek.

Water temperatures were measured by continuous thermograph recorders at each of the gaging stations.

\section{ANALYSIS AND INTERPRETATION OF THE DATA}

The principal method used to evaluate the effects of logging was to relate prelogging streamflow, sediment transport, and water temperatures of Needle Branch and Deer Creek to those of the control stream, Flynn Creek, and to compare the relations with postlogging data. Regression lines and their equations were developed using standard correlation methods (Ezekiel and Fox, 1959) to describe the prelogging relations. From these equations, values of dependent variables (Needle Branch and Deer Creek) can be estimated or predicted from values of the independent variable (Flynn Creek).

Prediction limits at the 95-percent level were computed for the streamflow, sediment-transport, and water-temperature prelogging relations to determine the significance of changes after logging. These prelogging relations and prediction limits contained in a report by Harris and Williams (1971, p. 7-20) are shown in table 1 . The prediction limits are the limits outside of which there is 95-percent confidence that a change has occurred. The 95-percent confidence level was arbitrarily chosen to indicate the great likelihood of a change. If the mean of postlogging values plots outside the prediction limits, the change is considered to be significant. The use of prediction and confidence limits is described by Snedecor (1956).

In this analysis, the prelogging relations were used to determine predicted postlogging values. Predicted values were computed for 
TABLE 1.-Prediction equations derived from analyses of prelogging data [Data from Harrıs and Willams (1971)]

1. Annual runnoff (in.)

Needle Branch $=(0.91)($ Flynn $)+3.52$

Deer Creek $=(1.02)$ Flynn $)-4.20$

2. Peak flow $\left(\mathrm{ft}^{3 /} / \mathrm{s}\right)$

Needle Branch $=(0.94)($ Flynn $)+20.7$

Deer Creek $=(0.92)($ Flynn $)+9.5$

3. Three-day high flow $\left(\mathrm{ft}^{3} / \mathrm{s} \times\right.$ days $)$

Needle Branch $=(1.04)($ Flynn $)+0.02$

Deer Creek $=(1.02)($ Flynn $)-0.09$

4. Low flow $\left(\mathrm{ft}^{3 / \mathrm{s}}\right)$

Needle Branch $=(0.27)($ Flynn $)-0.02$

Deer Creek $=(1.22)($ Flynn $)+0.15$

5. Discharge-weighted mean sediment concentration ( $\mathrm{mg} / \mathrm{l})$

Needle Branch $=(1.90)(\text { Flynn })^{0.72}$

Deer Creek $=(1.70)$ (Flynn $)^{0.87}$

6. Annual sediment yield (tons per square mile)

Needle Branch $=(3.31)(\text { Flynn })^{0.70}$

Deer Creek $=(2.24)(\mathrm{Flynn})^{0.86}$

7. Monthly maximum water temperature $\left({ }^{\circ} \mathrm{C}\right.$ ) (April-October)

Needle Branch ${ }^{1}=(0.87)($ Flynn $)+1.9$

Deer Creek $^{1}=(0.76)($ Flynn $)+3.7$

${ }^{1}$ Converted to degrees Celsius from formula in 1971 report

Needle Branch and Deer Creek by inserting the mean of postlogging values for Flynn Creek into the prelogging relation equations. The mathematically predicted values for Needle Branch and Deer Creek were compared to the actual postlogging means to determine if changes had occurred after logging and if the changes were significant. Individual postlogging values have been shown on some figures in this report for illustrative purposes only. The mean of the individual postlogging values provides the only valid comparison with the prediction limit to evaluate the statistical significance of the change.

In addition to the method of comparing predicted and actual values, changes in annual runoff in relation to precipitation were also evaluated by covariance analysis. This statistical method, which is described by Dixon and Massey (1957, p. 209-219), provides a means to evaluate the change between the prelogging and postlogging relations.

\section{PRECIPITATION}

Annual precipitation at the three precipitation gages in the Alsea study area and at a nearby National Weather Service gage at Tidewater, Oreg., (fig. 1) are shown in table 2. Precipitation in the study area is generally greater than that at Tidewater, but the timing of precipitation is generally the same because of the close geographic 
TABLE 2.-Annual precipitation, in inches

\begin{tabular}{|c|c|c|c|c|}
\hline $\begin{array}{l}\text { Water } \\
\text { year }\end{array}$ & Tidewater & $\begin{array}{l}\text { Flynn } \\
\text { Creek }\end{array}$ & $\begin{array}{l}\text { Needle } \\
\text { Branch }\end{array}$ & $\begin{array}{c}\text { Deer } \\
\text { Creek }\end{array}$ \\
\hline 1959 & 102.31 & 103.70 & 115.76 & 109.00 \\
\hline ( & 81.64 & 82.29 & 91.81 & 88.34 \\
\hline 1961 & 100.77 & 105.86 & 109.84 & 111.29 \\
\hline $1962 \ldots$ & 84.60 & 85.68 & 90.54 & 88.52 \\
\hline 1963 & 87.56 & 83.59 & 87.52 & 88.05 \\
\hline non & 91.87 & 95.34 & 96.63 & 99.02 \\
\hline 1965 & 90.90 & 94.09 & 92.30 & 98.24 \\
\hline Prelogging mean & 91.38 & 92.93 & 97.77 & 97.49 \\
\hline 1966 (logging) & 89.09 & 88.54 & 83.74 & 92.41 \\
\hline 1967 & 94.34 & 96.20 & 99.76 & 101.00 \\
\hline 1968 & 93.81 & ${ }^{1}(65.23)$ & ${ }^{1}(65.37)$ & ${ }^{1}(66.85)$ \\
\hline 1969 & 101.45 & $-\ldots$ & $-\ldots$ & $-\cdots$ \\
\hline 1970 & 90.58 & $\ldots$ & -...- & -..- \\
\hline $1971 \ldots$ & 111.59 & $-\ldots$ & -..- & $-\ldots$ \\
\hline $1972 \ldots$ & 114.22 & $-\cdots$ & -.... & -... \\
\hline 1973 & $\underline{71.19}$ & $\ldots$ & $\ldots$ & $=\cdots$ \\
\hline Postlogging mean & 96.74 & $\ldots$ & $\ldots$ & ---- \\
\hline
\end{tabular}

${ }^{1}$ Five months, October through February.

proximity of Tidewater to the study area. Precipitation data for the study area were collected only through February 1968 when precipitation measurements were discontinued. Data from the Tidewater gage indicate that the greatest and least annual precipitation during the entire study period occurred in consecutive years, 1972 and 1973, respectively. Monthly precipitation at the Tidewater gage for these 2 extreme years is shown in figure 5. The illustration depicts the general precipitation characteristics of the area; that is, heavy in winter and spring and light in summer.

To interpret correctly the effects of logging on streamflow, sedimentation, and water temperature, the normal areal weather pattern should not change during the study period. A change in the normal weather pattern could conceivably result in changes in hydrologic characteristics of the logged watersheds in relation to the control watershed; these changes in hydrologic characteristics might then be falsely attributed to logging. Annual precipitation amounts at the three watersheds provide an index to help verify that no changes have occurred in the weather pattern. If no change occurs in the areal distribution of precipitation but hydrologic characteristics change after logging, then the changes in hydrologic characteristics would most likely be the result of logging.

Cumulative annual precipitation data collected at Needle Branch and Deer Creek was related to cumulative annual precipitation data at Flynn Creek (fig. 6). The lines of the relations before and after logging show no appreciable change. This lack of change infers that 


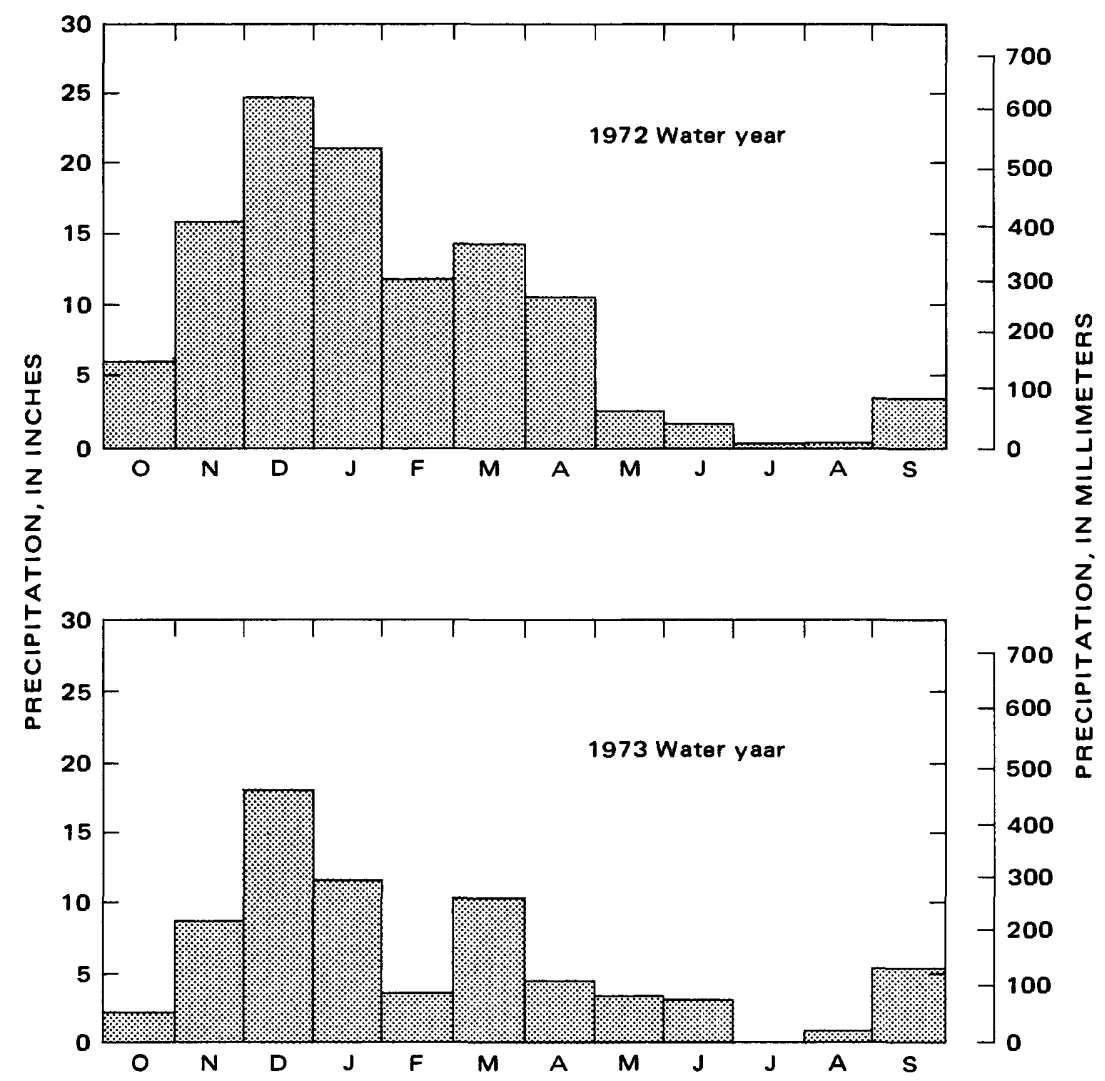

Figure 5.-Monthly precipitation at Tidewater, Oreg., October-September, 1972 and 1973.

there was no change in areal distribution of precipitation after logging.

\section{STREAMFLOW}

Selected streamflow characteristics were used in this analysis as indexes of stream regimen. Annual runoff was used as an index of the total amount of surface water (excluding evapotranspiration) leaving the watersheds. Peak flows and 3-day high-flow volumes were used as indexes of high flow. Instantaneous peak flows represent the maximum high flow, and 3-day high-flow volumes represent the volume of water leaving the watersheds during storm periods. Minimum daily flows during August and September, the months of lowest flows, were used as an index of low flow.

\section{ANNLAL RUNOFF}

Annual runoff for the three watersheds during the prelogging, log- 

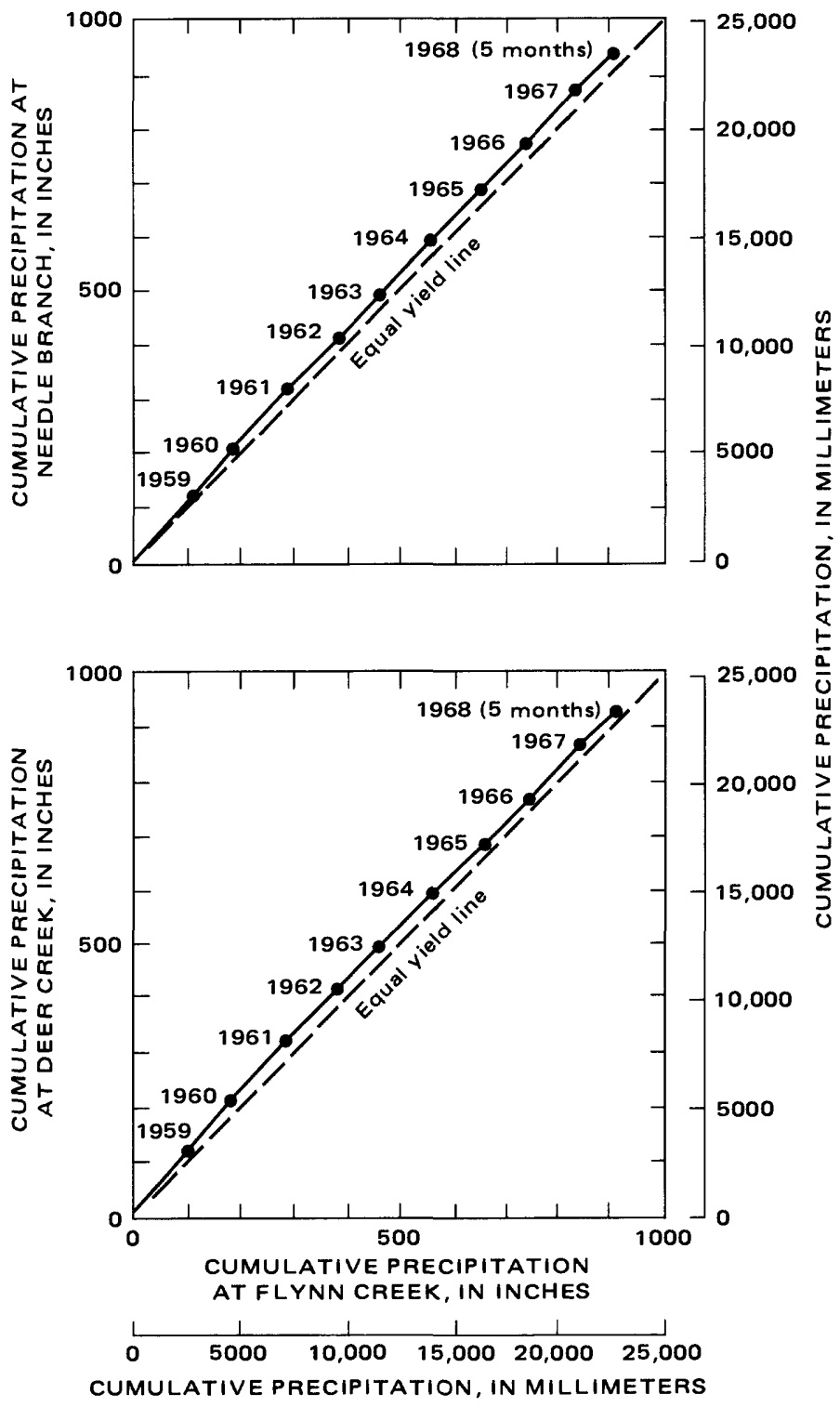

FigURE 6.-Relation of cumulative precipitation at Needle Branch and Deer Creek gages to that at Flynn Creek gage.

ging, and postlogging periods is shown in table 3. On Flynn Creek, mean runoff was slightly lower during the postlogging period than during the prelogging period, whereas on Needle Branch and Deer Creek, runoff was higher during the postlogging period. The highest and lowest annual runoffs for all three sites occurred in 2 successive 
TABLE 3.-Annual runoff, in inches

\begin{tabular}{|c|c|c|c|}
\hline Water year & $\begin{array}{l}\text { Flynn } \\
\text { Creek }\end{array}$ & $\begin{array}{l}\text { Needle } \\
\text { Branch }\end{array}$ & $\begin{array}{c}\text { Deer } \\
\text { Creek }\end{array}$ \\
\hline $\begin{array}{l}1959 \\
1960 \\
1962 \\
1963 \\
1964\end{array}$ & $\begin{array}{l}78.60 \\
72.18 \\
93.30 \\
66.45 \\
69.17 \\
77.21 \\
87.07\end{array}$ & $\begin{array}{l}84.04 \\
69.55 \\
85.56 \\
61.61 \\
62.83 \\
75.28 \\
80.80 \\
\end{array}$ & $\begin{array}{l}78.63 \\
67.81 \\
89.64 \\
64.27 \\
64.68 \\
74.90 \\
85.47 \\
\end{array}$ \\
\hline Prelogging mean & 77.71 & 74.24 & 75.06 \\
\hline 1966 (logging) & 67.74 & 68.26 & 67.34 \\
\hline $\begin{array}{l}1967 \\
1968 \\
1969 \\
1970 \\
1972\end{array} 1973$ & $\begin{array}{r}75.74 \\
68.01 \\
86.70 \\
64.98 \\
86.92 \\
109.59 \\
47.04 \\
\end{array}$ & $\begin{array}{r}86.98 \\
85.55 \\
106.93 \\
80.51 \\
106.98 \\
124.50 \\
56.92 \\
\end{array}$ & $\begin{array}{r}72.79 \\
69.44 \\
82.93 \\
67.16 \\
90.54 \\
106.05 \\
48.98 \\
\end{array}$ \\
\hline Postlogging mean & 77.00 & 92.62 & 76.84 \\
\hline
\end{tabular}

years, 1972 and 1973, respectively. Figure 7 shows the runoff pattern at Flynn Creek for these 2 years.

After logging on Needle Branch, the actual mean runoff of 92.62 in. $(2,353 \mathrm{~mm})$ is $19.03 \mathrm{in}$. $(483 \mathrm{~mm})$, or 26 percent greater than the predicted runoff of $73.59 \mathrm{in} .(1,869 \mathrm{~mm})$.

After logging on Deer Creek, the actual mean runoff of $76.84 \mathrm{in}$. $(1,952 \mathrm{~mm})$ after logging is $2.50 \mathrm{in} .(63.5 \mathrm{~mm})$ or 3 percent greater than the predicted runoff of 74.34 in. $(1,888 \mathrm{~mm})$.

Figure 8 shows that the runoff of Needle Branch after logging increased significantly beyond the prediction limits, whereas the slight increase of Deer Creek was not statistically significant. There was no conclusive evidence of a return to prelogging runoff conditions on Needle Branch as of the 1973 water year.

A covariance analysis was made using precipitation at Tidewater and annual runoff of Needle Branch and Deer Creek. For Needle Branch, the analysis indicates that (1) there is a significant difference in prelogging and postlogging runoff means, (2) the relations between hydrologic characteristics of watersheds before and after logging are significantly different, and (3) the slope of the regression lines before and after logging are parallel. For Deer Creek, the analysis indicates that there is no significant difference in prelogging and postlogging runoff means and that there is no significant difference between the prelogging and postlogging regression lines of relation.

The relation of cumulative annual runoff of Needle Branch and Deer Creek to that of Flynn Creek, shown in figure 9, indicates a noticeable increase in runoff of Needle Branch and a slight increase in runoff of Deer Creek after logging. 

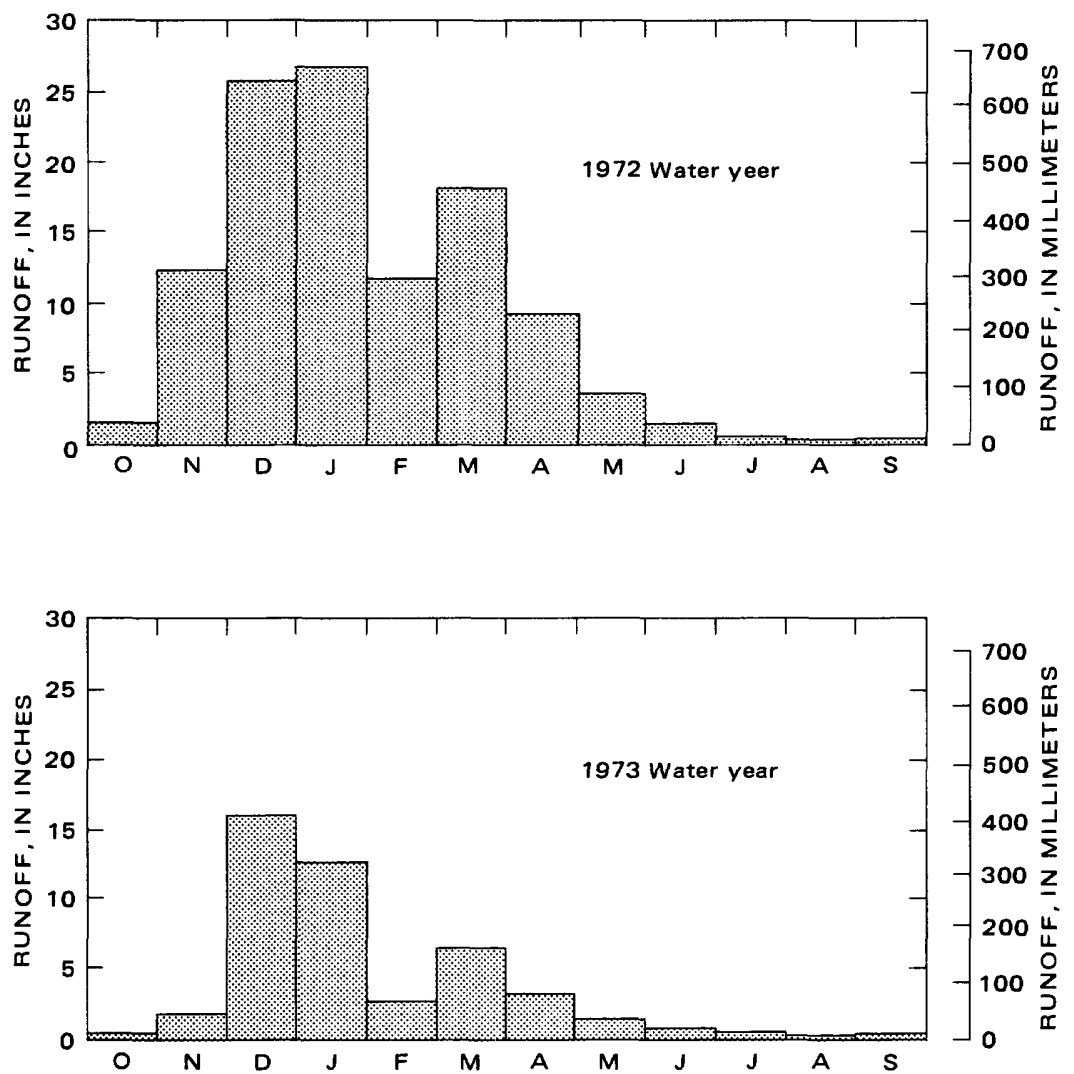

Figure 7.-Monthly runoff of Flynn Creek, October-September, 1972 and 1973.

HIGH FIOOW

Peak flows of $50\left(\mathrm{ft}^{3} / \mathrm{s}\right) / \mathrm{mi}^{2}\left[0.55\left(\mathrm{~m}^{3} / \mathrm{s}\right) / \mathrm{km}^{2}\right]$ or greater for the three study streams during the prelogging and postlogging periods are given in table 4 . The table shows that for Flynn Creek the mean of the peaks was slightly greater during the prelogging period than after logging, whereas after logging the mean of the peaks increased markedly on Needle Branch and slightly on Deer Creek.

After logging on Needle Branch, the actual mean of peak flows increased $17.8\left(\mathrm{ft}^{3} / \mathrm{s}\right) / \mathrm{mi}^{2}\left[0.19\left(\mathrm{~m}^{3} / \mathrm{s}\right) / \mathrm{km}^{2}\right]$, or 20 percent greater than the predicted mean of $91.2\left(\mathrm{ft}^{3} / \mathrm{s}\right) / \mathrm{mi}^{2}\left[1.0\left(\mathrm{~m}^{3} / \mathrm{s}\right) / \mathrm{km}^{2}\right]$.

After logging on Deer Creek, the actual mean of the peak flows increased $1.8\left(\mathrm{ft}^{3} / \mathrm{s}\right) \mathrm{mi}^{2}\left[0.02\left(\mathrm{~m}^{3} / \mathrm{s}\right) / \mathrm{km}^{2}\right]$, or 2 percent greater than the predicted mean of $78.5\left(\mathrm{ft}^{3} / \mathrm{s}\right) / \mathrm{mi}^{2}\left[0.86\left(\mathrm{~m}^{3} / \mathrm{s}\right) / \mathrm{km}^{2}\right]$.

A comparison of Needle Branch postlogging peak flows to the pre- 


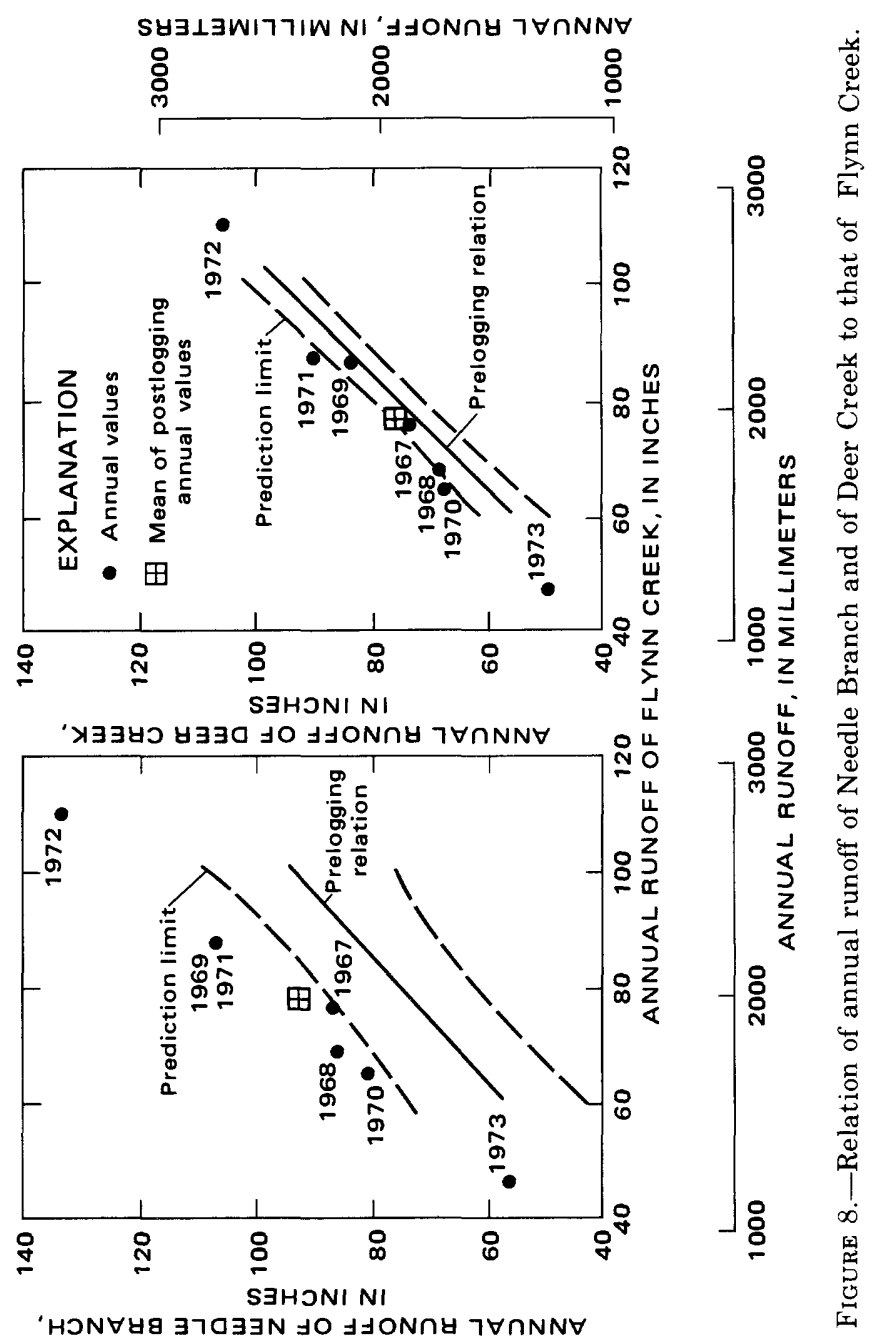



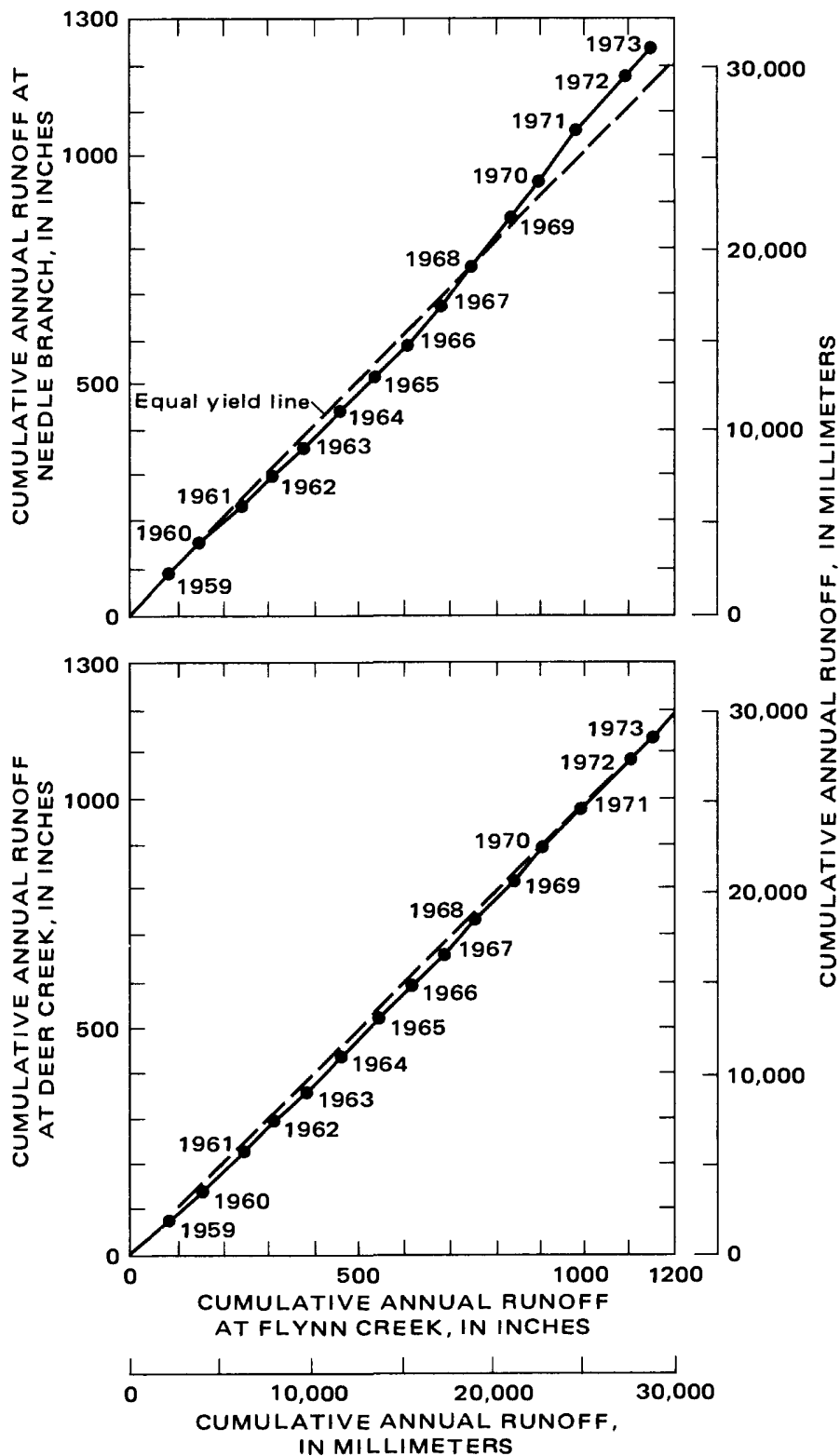

Figure 9.-Relation of cumulative annual runoff of Needle Branch and of Deer Creek to that of Flynn Creek.

logging relation and prediction limits (fig. 10) shows a noticeable increase in peak flows after logging. However, because mean of the peaks falls inside the prediction limits, the increase is not statisti- 
TABLE 4.-Peak discharges and runoffs for all peaks greater than $50\left(f t^{3} / s\right) / m i^{2}$ on Flynn Creek and concurrent peaks on Needle Branch and Deer Creek

\begin{tabular}{|c|c|c|c|c|c|c|c|}
\hline \multirow[b]{2}{*}{$\begin{array}{l}\text { Water } \\
\text { year }\end{array}$} & \multirow[b]{2}{*}{ Date } & \multicolumn{2}{|c|}{ Flynn Creek } & \multicolumn{2}{|c|}{ Needle Branch } & \multicolumn{2}{|c|}{ Deer Creek } \\
\hline & & $\begin{array}{c}\text { Peak } \\
\text { discharge } \\
\text { (ft } \mathrm{ft}^{3 / \mathrm{s}} \text { ) }\end{array}$ & $\begin{array}{c}\text { Runoff } \\
{\left[\mathrm{f} \mathrm{ft}^{3 /} / \mathrm{s} / \mathrm{mi}^{2}\right]}\end{array}$ & $\begin{array}{c}\text { Peak } \\
\text { discharge } \\
\left(\mathrm{ft}^{3} / \mathrm{s}\right)\end{array}$ & $\begin{array}{c}\text { Runoff } \\
{\left[\left(\mathrm{ft}^{3 /} / \mathrm{s} / \mathrm{mi}^{2}\right]\right.}\end{array}$ & $\begin{array}{c}\text { Peak } \\
\text { discharge } \\
\text { (ft }\end{array}$ & $\begin{array}{c}\text { Runoff } \\
{\left[\mathrm{ft}^{3} / \mathrm{s} / \mathrm{mi}^{2}\right]}\end{array}$ \\
\hline 1959 & _- Jan. 9 & 53 & 67.9 & 22 & 81.5 & 83 & 70.9 \\
\hline & 27 & 42 & 53.8 & 19 & 70.4 & 71 & 60.7 \\
\hline 1960 & Feb. 9 & 43 & 55.1 & 20 & 74.1 & 67 & 57.3 \\
\hline \multirow[t]{3}{*}{1961} & Nov. 24 & 78 & 100.0 & 33 & 122.2 & 114 & 97.4 \\
\hline & Feb. 10 & 64 & 82.1 & 28 & 103.7 & 106 & 90.6 \\
\hline & 13 & 47 & 60.3 & 18 & 66.7 & 76 & 65.0 \\
\hline \multirow[t]{3}{*}{1962} & Nov. 22 & 46 & 59.0 & 29 & 107.4 & 81 & 69.2 \\
\hline & Dec. 19 & 41 & 52.6 & 18 & 66.7 & 67 & 57.3 \\
\hline & 20 & 43 & 55.1 & 17 & 63.0 & 65 & 55.6 \\
\hline 1963 & Nov. 26 & 65 & 83.3 & 28 & 103.7 & 105 & 89.7 \\
\hline \multirow[t]{2}{*}{1964} & Jan. 19 & 63 & 80.8 & 28 & 103.7 & 96 & 82.1 \\
\hline & 25 & 40 & 51.3 & 17 & 63.0 & 63 & 53.8 \\
\hline \multirow[t]{4}{*}{1965} & Dec. 1 & 43 & 55.1 & 17 & 63.0 & 70 & 59.8 \\
\hline & 22 & 90 & 115.4 & 32 & 118.5 & 130 & 111.1 \\
\hline & Jan. 28 & 137 & 175.6 & 50 & 185.2 & 201 & 171.8 \\
\hline & Prelogging mean & ... & 76.5 & -- & 92.9 & -- & 79.5 \\
\hline 1967 & -- Jan. 27 & 70 & 89.7 & 33 & 122.2 & 105 & 89.7 \\
\hline 1968 & Feb. 19 & 45 & 57.7 & 25 & 92.6 & 80 & 68.4 \\
\hline \multirow[t]{3}{*}{1969} & Dec. 4 & 45 & 57.7 & 124 & 88.9 & 70 & 59.8 \\
\hline & 10 & 43 & 55.1 & 124 & 88.9 & 70 & 59.8 \\
\hline & Jan. 7 & 41 & 52.6 & 120 & 74.1 & 72 & 61.5 \\
\hline \multirow[t]{3}{*}{1970} & Jan. 18 & 50 & 64.1 & 25 & 92.6 & 76 & 65.0 \\
\hline & 23 & 43 & 55.1 & 22 & 81.5 & 78 & 66.7 \\
\hline & 27 & 45 & 57.7 & 19 & 70.4 & 73 & 62.4 \\
\hline \multirow{3}{*}{1971} & Dec. 30 & 58 & 74.4 & 31 & 114.8 & 114 & 97.4 \\
\hline & Jan. 16 & 51 & 65.4 & ${ }^{2} 31$ & 114.8 & 75 & 64.1 \\
\hline & 25 & 41 & 52.6 & 22 & 81.5 & 74 & 63.2 \\
\hline \multirow[t]{3}{*}{1972} & Jan. 11 & 139 & 178.2 & 64 & 237.0 & 196 & 167.5 \\
\hline & 20 & 119 & 152.6 & 48 & 177.8 & 172 & 147.0 \\
\hline & Mar. 2 & 48 & 61.5 & 25 & 92.6 & 74 & 63.2 \\
\hline \multirow[t]{3}{*}{1973} & Dec. 21 & 56 & 71.8 & 36 & 133.3 & 115 & 98.3 \\
\hline & 27 & 42 & 53.8 & 22 & 81.5 & 60 & 51.3 \\
\hline & Postlogging mean & -.. & 75.0 & $\ldots$ & 109.0 & -- & 80.3 \\
\hline
\end{tabular}

${ }^{1}$ Peaks were incorrectly published for 1 day later than shown.

2 Occurred on January 15.

cally significant. Changes in peak flows of Deer Creek after logging were statistically undetectable.

Three-day high-flow runoff totals for storm periods on Flynn Creek, Needle Branch, and Deer Creek are given in table 5. The mean of these totals for Flynn Creek during the postlogging period is $4.58 \mathrm{in}$. $(116 \mathrm{~mm})$ compared to a mean of $4.50 \mathrm{in} .(114 \mathrm{~mm})$ for the prelogging period. Storm runoff during the postlogging period was 0.08 in. $(2.0 \mathrm{~mm})$ greater than during the prelogging period. In comparison, storm runoff in the postlogging period was $1.21 \mathrm{in} .(31 \mathrm{~mm})$ greater for Needle Branch and 0.10 in. $(2.5 \mathrm{~mm})$ greater for Deer Creek.

On Needle Branch, the predicted mean of the 3-day high flow was $4.78 \mathrm{in}$. (121 mm) after logging compared to an actual mean of 5.91 


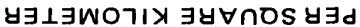

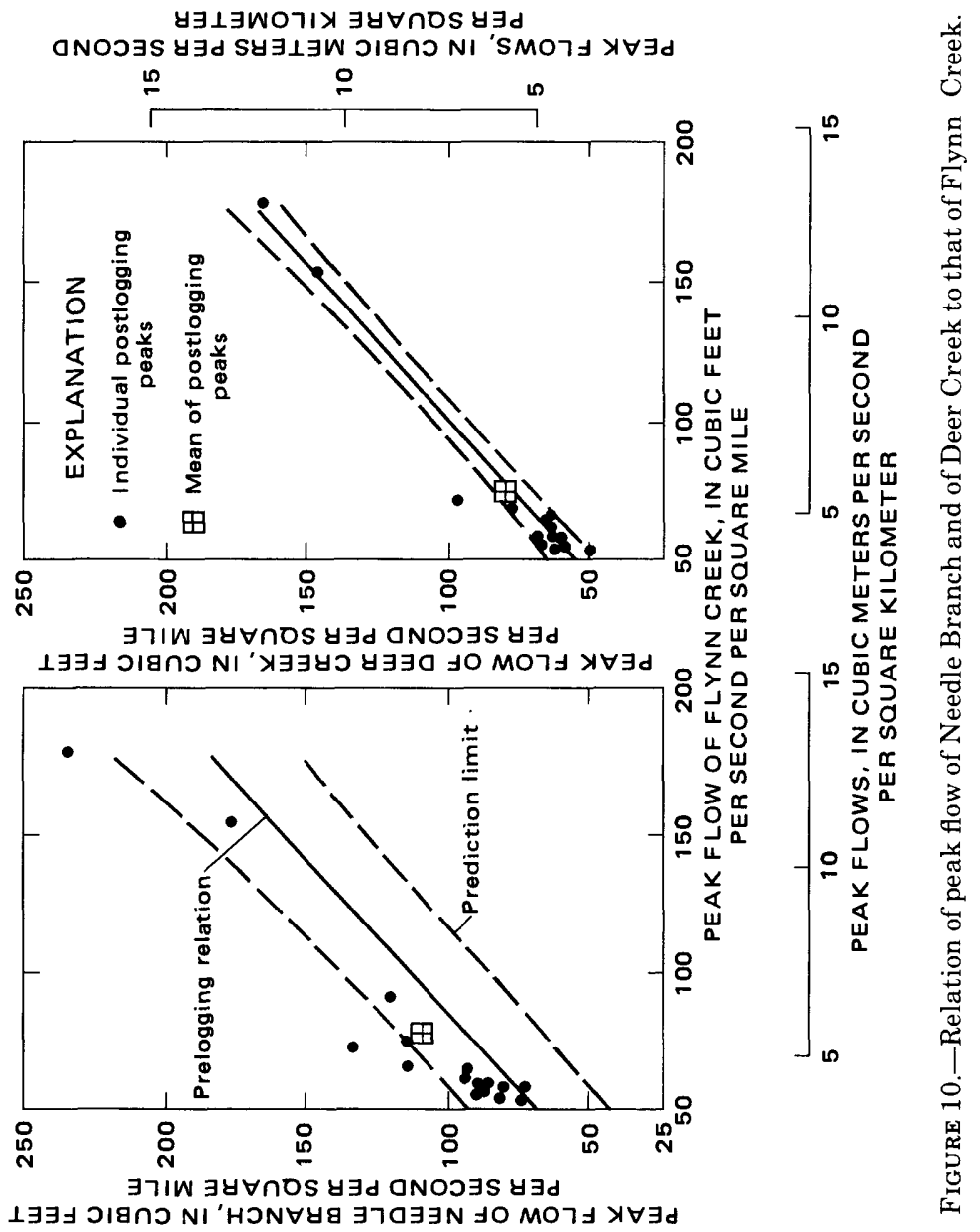


TABLE 5.-Three-day high-flow runoff for Flynn Creek, Needle Branch, and Deer Creek

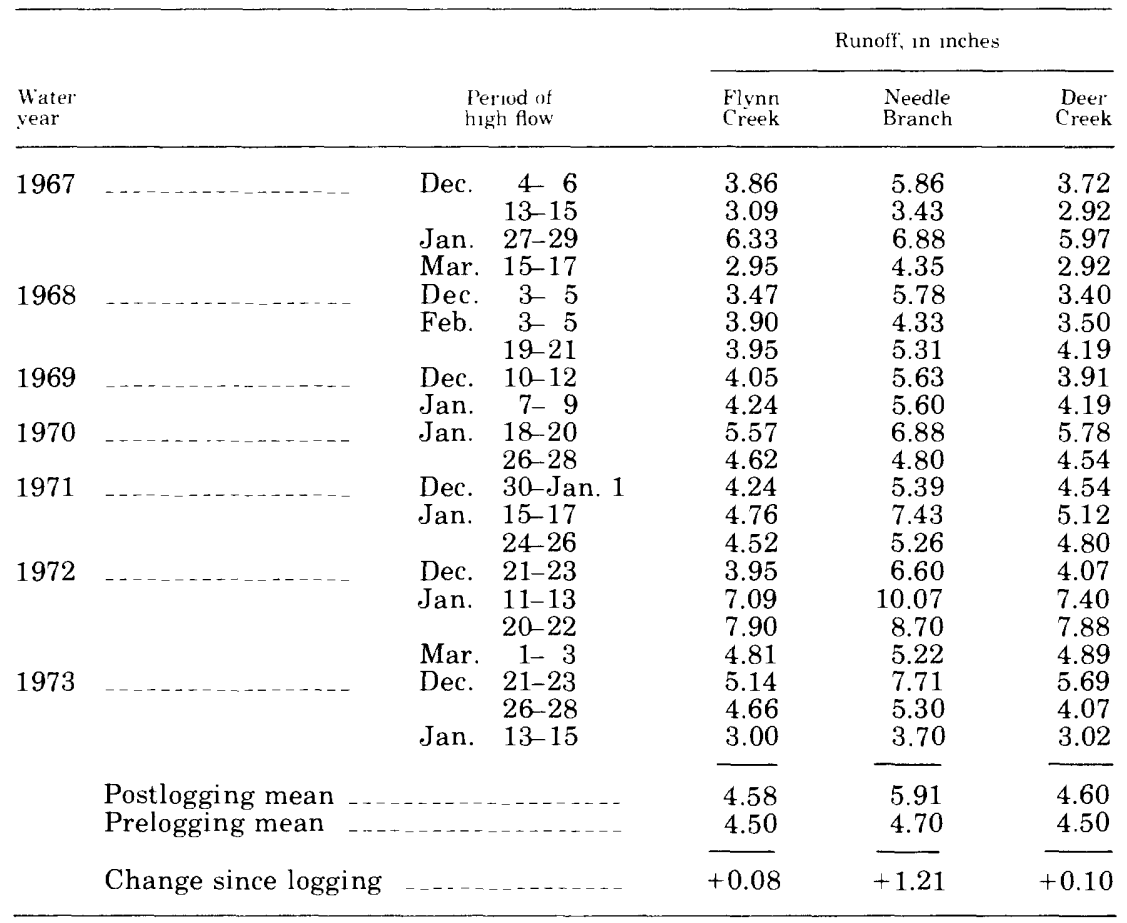

in. $(150 \mathrm{~mm})$. On Deer Creek the predicted mean was $4.58 \mathrm{in}$. $(116 \mathrm{~mm})$ compared to an actual mean of 4.60 in. (117 $\mathrm{mm}$ ).

A comparison of the postlogging 3-day high flow to the prelogging relation and prediction limit is shown in figure 11 . The increase in storm runoff on Needle Branch was statistically significant, whereas the change on Deer Creek was not significant.

\section{OW FLOW}

Minimum daily August-September flows in Flynn Creek and concurrent flows in Needle Branch and Deer Creek for the prelogging, logging, and postlogging periods are given in table 6 . The table shows that mean low flows in Flynn and Deer Creeks were lower during the logging and postlogging periods than those during the prelogging period. Also, the postlogging mean low flows for these two sites were higher than those for the logging period (1966). In contrast, low flow in Needle Branch during the logging period was slightly greater than during prelogging period. In the postlogging period, the predicted mean low flow based on prelogging data of $0.03 \mathrm{ft}^{3} / \mathrm{s}\left(0.0008 \mathrm{~m}^{3} / \mathrm{s}\right)$ is the same as the actual low flow. On Deer Creek, the actual mean low 

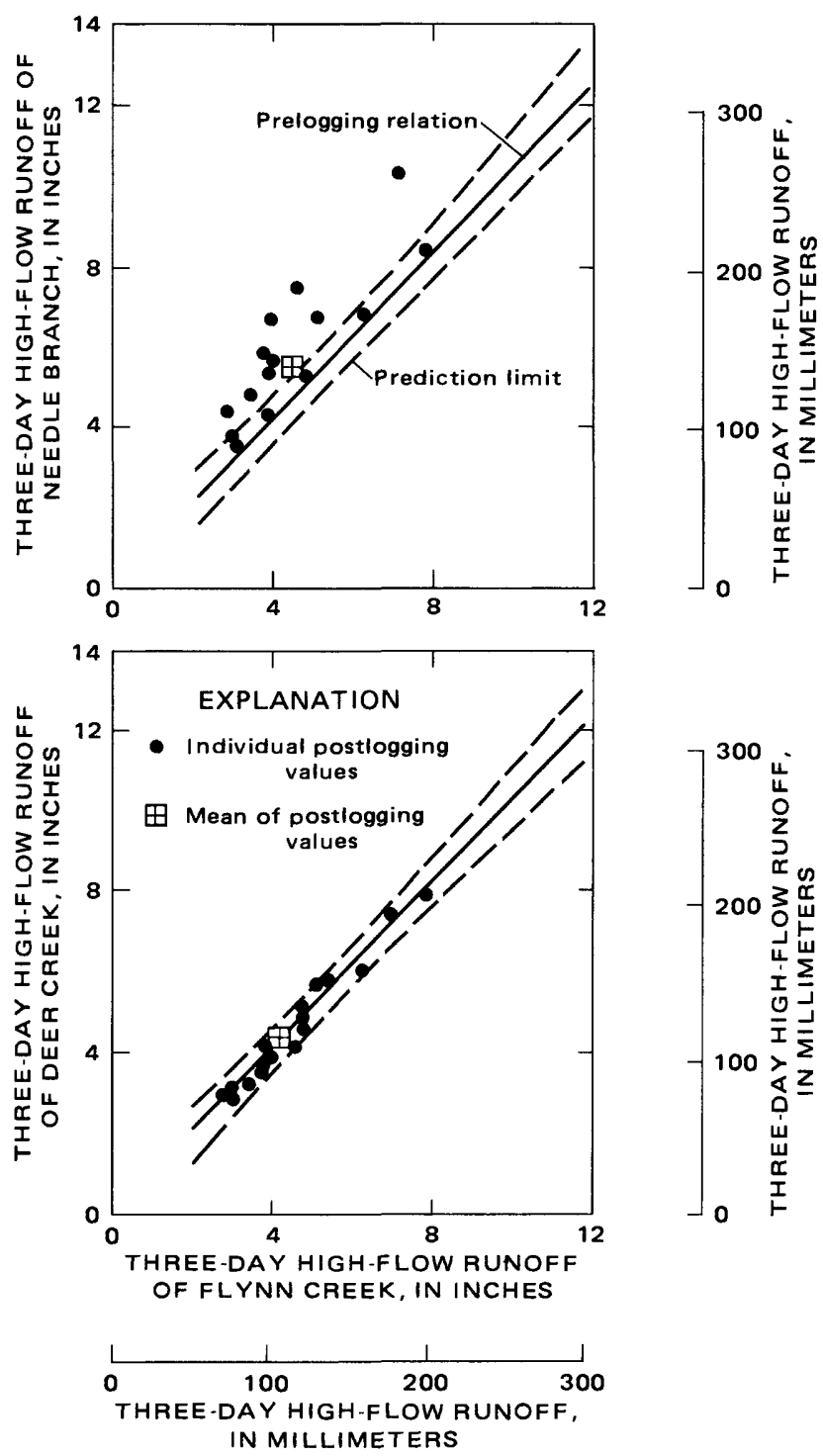

Figure 11.-Relation of 3-day high-flow runoff of Needle Branch and of Deer Creek to that of Flynn Creek.

flow is $0.29 \mathrm{ft}^{3} / \mathrm{s}\left(0.008 \mathrm{~m}^{3} / \mathrm{s}\right)$ which is $0.07 \mathrm{ft}^{3} / \mathrm{s}\left(0.002 \mathrm{~m}^{3} / \mathrm{s}\right)$, or 19 percent less than predicted low flow.

Comparisons of low flows for the logging and postlogging periods to the prelogging regression lines are shown in figure 12. On the basis of the analytical method used, changes in low flows since logging are not statistically significant. Although the postlogging data are well 
TABLE 6.-Minimum daily August-September flows, in cubic feet per second, Flynn Creek and concurrent flows of Needle Branch and Deer Creek

\begin{tabular}{lcrr}
\hline Water year & $\begin{array}{c}\text { Flynn } \\
\text { Creek }\end{array}$ & $\begin{array}{c}\text { Needle } \\
\text { Branch }\end{array}$ & $\begin{array}{c}\text { Deer } \\
\text { Creek }\end{array}$ \\
\hline & Prelogging period & & \\
\hline 1959 & 0.25 & 0.05 & 0.50 \\
1960 & .14 & .02 & .31 \\
1961 & .18 & .02 & .34 \\
1962 & .02 & .35 \\
1963 & .21 & .03 & .47 \\
1964 & .03 & .43 \\
1965 & .12 & .01 & .24 \\
\hline Mean & $\underline{10.19}$ & 20.03 & ${ }^{3} 0.38$ \\
\hline
\end{tabular}

Logging period

\begin{tabular}{rrrrr}
\hline 1966 & & ${ }^{4} 0.11$ & ${ }^{5} 0.04$ & ${ }^{6} 0.23$ \\
\hline 1967 & Postlogging period & \\
1968 & & 0.09 & 0.02 & 0.18 \\
1969 & .31 & .07 & .48 \\
1970 & .18 & .04 & .26 \\
1971 & .22 & .02 & .40 \\
1972 & .12 & .01 & .19 \\
1973 & $\frac{.14}{70}$ & $\frac{.01}{87}$ & ${ }^{9} 0.29$ \\
\hline
\end{tabular}

${ }^{1} 0.24\left(\mathrm{ft}^{3} / \mathrm{s}\right) / \mathrm{ml}^{2} . \quad{ }^{4} 0.14\left(\mathrm{ft}^{3} / \mathrm{s}\right) / \mathrm{mi}^{2} . \quad{ }^{7} 0.22\left(\mathrm{ft}^{3} / \mathrm{s}\right) / \mathrm{mi}^{2}$

${ }^{2} 0.11\left(\mathrm{ft}^{3} / \mathrm{s}\right) / \mathrm{mi}^{2} . \quad 50.15\left(\mathrm{ft}^{3} / \mathrm{s}\right) / \mathrm{mi}^{2}, \quad{ }^{8} 0.11\left(\mathrm{ft}^{3} / \mathrm{s}\right) / \mathrm{mi}^{2}$

${ }^{3} 0.32\left(\mathrm{ft}^{3} / \mathrm{s}\right) / \mathrm{mi}^{2} . \quad{ }^{6} 0.20\left(\mathrm{ft}^{3} / \mathrm{sl}^{2} / \mathrm{mi}^{2} . \quad{ }^{9} 0.25\left(\mathrm{ft}^{3} / \mathrm{s}\right) / \mathrm{ml}^{2}\right.$

NoTE.-Discharge figures presented in annual data reports prior to 1964 were rounded to the nearest tenth of a cubic foot per second.

within the prediction limits established using prelogging data (Harris and Williams, 1971, p. 13), figure 12 shows a postlogging trend with time toward decreased low flows. Needle Branch low flows immediately after logging seemed higher than expected from the prelogging relation, but generally decreased each subsequent year toward the prelogging relation. In contrast, Deer Creek low flows immediately after logging seem to be close to the prelogging relation and, although the time trend is not so evident as that for Needle Branch, there seems to be an overall decrease in low flow during the postlogging period.

Comparisons of hydrograph recession rates indicate no detectable change in the low-flow recession rates from prelogging rates.

Using data through 1971, Harr and Krygier (1972) found that the number of daily flows of less than $1\left(\mathrm{ft}^{3} / \mathrm{s}\right) / \mathrm{mi}^{2}\left[0.01\left(\mathrm{~m}^{3} / \mathrm{s}\right) / \mathrm{km}^{2}\right] \mathrm{de}-$ creased for Needle Branch and Deer Creek after logging in comparison to those for Flynn Creek. They found that Deer Creek showed a significant decrease in number of low-flow days for only 2 of the 5 


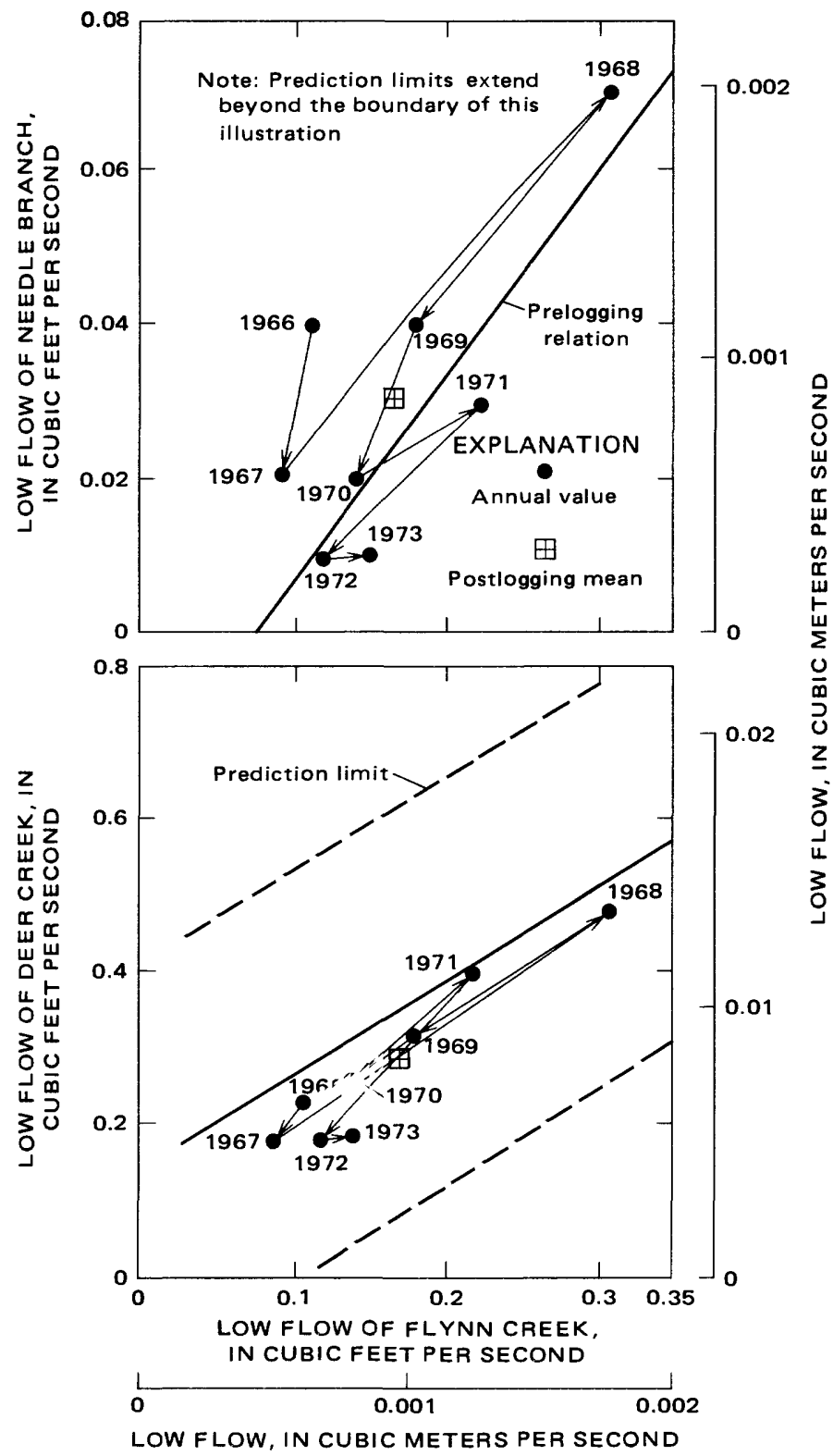

Figure 12.--Relation of low flow of Needle Branch and of Deer Creek to that of Flynn Creek.

postlogging years. A comparison of data for 1972 and 1973 with Harr and Krygier's relationships indicates that the decrease in number of low-flow days is still apparent for Deer Creek; however, the number 
TABLE 7.-Maximum mean daily sediment concentrations, in milligrams per litre

\begin{tabular}{lrrr}
\hline & \multicolumn{1}{c}{ Flynn Creek } & \multicolumn{1}{c}{ Needle Branch } & \multicolumn{1}{c}{ Deer Creek } \\
\hline Prelogging (1959-65) & $1580(1-28-65)$ & $300(1-28-65)$ & $1220(1-28-65)$ \\
Logging (1966) & $390(12-27-66)$ & $477(12-27-66)$ & $1010(12-27-66)$ \\
Postlogging (1967-73) $\ldots---$ & $1530(1-11-72)$ & $1260(2-18-68)$ & $2450(1-11-72)$ \\
\hline
\end{tabular}

of low-flow days appears to be increasing toward the prelogging condition for Needle Branch.

\section{SEDIMENT TRANSPORT}

Sediment-transport characteristics of the streams before and after logging are described by trend analyses of the sediment concentrations, yields, and particle-size distributions.

\section{SEDIMENT CONCENTRATION}

After logging, sediment concentrations increased significantly. Table 7 shows maximum daily mean sediment concentrations before, during, and after logging. Comparisons of annual discharge-weighted mean concentrations after logging to the prelogging relations are shown in figure 13. Prior to logging, average discharge-weighted mean concentrations, which are indexes of the sediment load in relation to water discharge, were $34.6,24.6$, and $37.6 \mathrm{mg} / \mathrm{l}$ for Flynn Creek, Needle Branch, and Deer Creek, respectively. Mean concentrations after logging were $40.0,67.1$, and $52.7 \mathrm{mg} / \mathrm{l}$ for these streams. The concentrations show a significant increase of $40.0 \mathrm{mg} / 1$ over the predicted value of $27.1 \mathrm{mg} / \mathrm{l}$ for Needle Branch and a large but not statistically significant increase of $10.6 \mathrm{mg} / \mathrm{l}$ over the predicted value of 42.1 for Deer Creek. Mean concentrations of Needle Branch returned to within the prelogging prediction limits during the last 2 years of the study (1972 and 1973)—6 years after logging.

\section{SEDIMENT Y'IELD}

Annual sediment yields of the three study drainages are shown in table 8. Comparisons of the postlogging yields to the prelogging statistical regression relations (fig. 14) show that yields increased significantly on Needle Branch and slightly on Deer Creek after logging. Brown and Krygier (1971) state that "The greatest changes [in sediment production] were associated with the road building operation that preceded logging and the controlled slash burning afterward." The greatest increases in yields occurred on both streams during the first year after logging, and yields are gradually returning to prelogging conditions with the passage of time. On Needle Branch, 

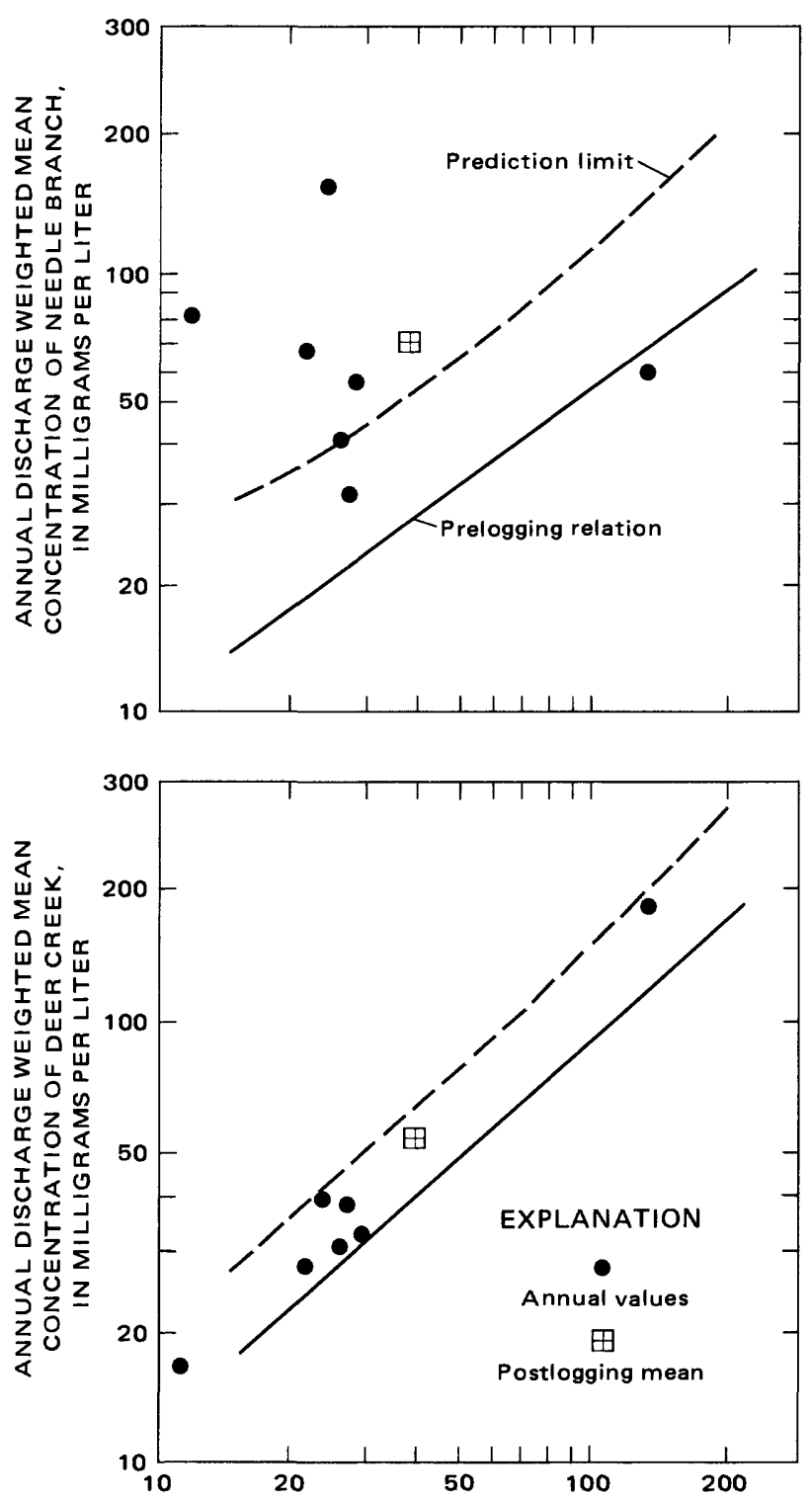

ANNUAL DISCHARGE WEIGHTED MEAN CONCENTRATION OF FLYNN CREEK, IN MILLIGRAMS PER LITER

Figure 13.-Relation of annual discharge-weighted mean sediment concentrations of Needle Branch and of Deer Creek to those of Flynn Creek. 
TABLE 8.-Annual sediment yields, in tons per square mile, of the three study watersheds

\begin{tabular}{|c|c|c|c|c|}
\hline & Water year & $\begin{array}{l}\text { Flynn } \\
\text { Creek }\end{array}$ & $\begin{array}{l}\text { Needle } \\
\text { Branch }\end{array}$ & $\begin{array}{c}\text { Deer } \\
\text { Creek }\end{array}$ \\
\hline \multirow[t]{2}{*}{$\begin{array}{l}1959 \\
1960 \\
1961 \\
1962 \\
1963 \\
1964 \\
1965\end{array}$} & $\begin{array}{r}{ } \\
-\end{array}$ & $\begin{array}{r}88 \\
65 \\
338 \\
138 \\
114 \\
226 \\
1,270\end{array}$ & $\begin{array}{r}59 \\
41 \\
186 \\
141 \\
117 \\
184 \\
430\end{array}$ & $\begin{array}{r}91 \\
91 \\
340 \\
118 \\
162 \\
213 \\
1,070\end{array}$ \\
\hline & Mean (prelogging period) & 320 & 165 & 298 \\
\hline \multicolumn{2}{|c|}{1966 (Logging period) } & 291 & 368 & 746 \\
\hline \multirow[t]{2}{*}{$\begin{array}{l}1967 \\
1968 \\
1969 \\
1970 \\
1971 \\
1972 \\
1973\end{array}$} & $\begin{array}{l}-{ } \\
-\end{array}$ & $\begin{array}{r}131 \\
67 \\
142 \\
121 \\
189 \\
1,103 \\
88\end{array}$ & $\begin{array}{l}905 \\
490 \\
515 \\
232 \\
415 \\
519 \\
132\end{array}$ & $\begin{array}{r}218 \\
87 \\
161 \\
147 \\
211 \\
1,411 \\
131\end{array}$ \\
\hline & Mean (postlogging period) & 263 & 458 & 338 \\
\hline
\end{tabular}

yields during the last 2 years of the study have decreased to within the prelogging prediction limits. The large changes in sediment yields after logging are graphically evident in the relations of cumulative sediment yields shown in figure 15. A return to prelogging conditions is portrayed by the gradual bending of the postlogging plotted lines toward the slopes of those defined by data of the prelogging period. From figure 15, the return to prelogging conditions is more evident for Needle Branch than for Deer Creek.

\section{PARTICLE-SIZE DISTRIBUTION}

Data collected on particle-size distribution of the sediment loads are not conclusive. Approximate size distributions of sampled sediment loads before, during, and after logging are shown in table 9 . Samples taken from all three streams during and after logging show some increase in the amount of coarse material. This increase in size of coarse material probably cannot be attributed entirely to logging, because the increase also shows up in Flynn Creek, whose watershed was not logged. Drifting organic material, such as bark, branches, and leaves, increased visibly on Needle Branch for a short time immediately after logging, but no samples were taken to document the amounts of debris.

\section{WATER TEMPERATURE}

Maximum and minimum water temperatures before and after logging are given in table 10 . Figure 16 shows the relations of maximum 

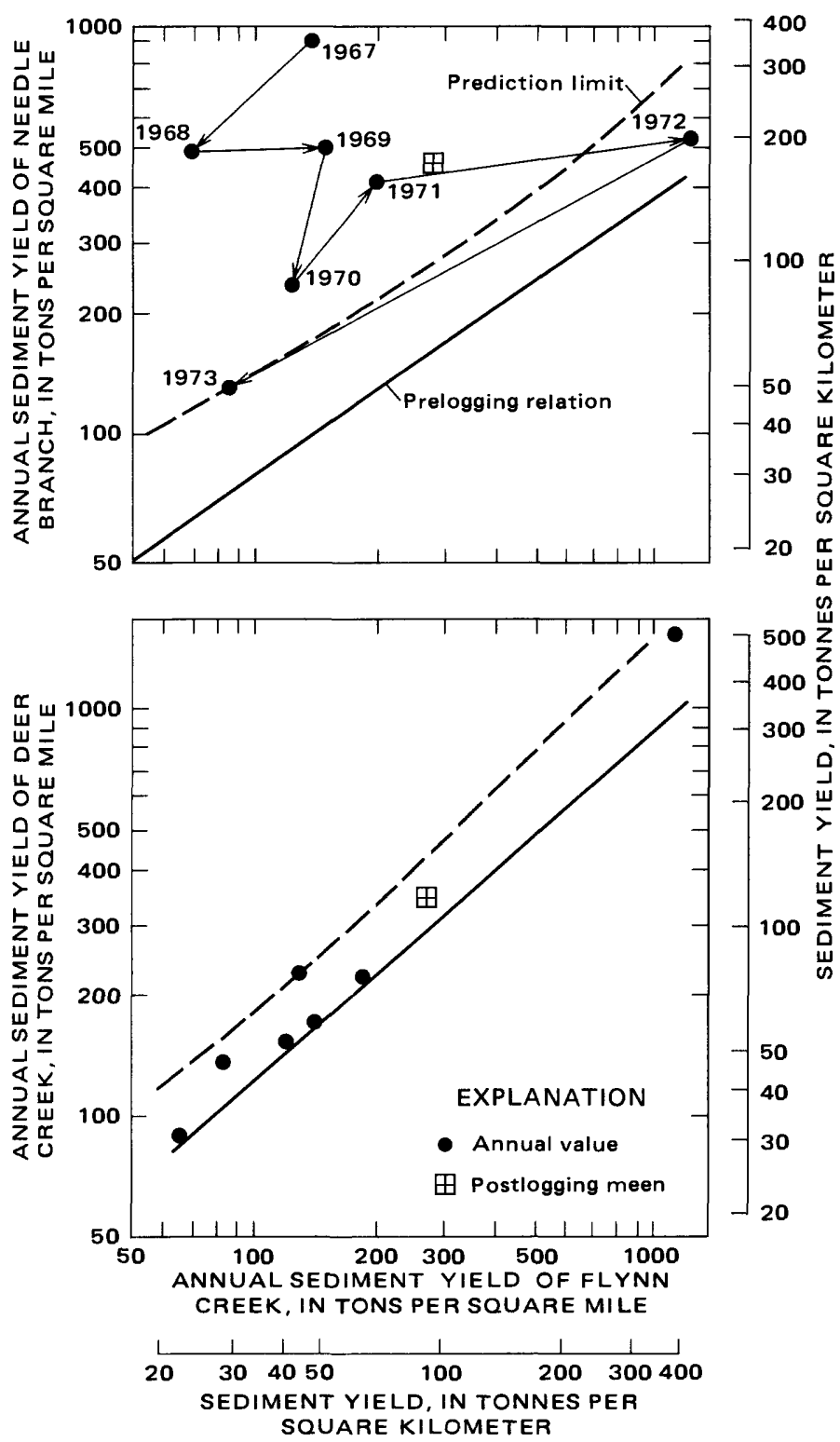

Figure 14.-Relation of annual sediment yields of Needle Branch and of Deer Creek watersheds to those of Flynn Creek watershed.

monthly water temperatures during April to October for the postlogging period compared to the prelogging maximum temperature relations and prediction limits. Needle Branch temperatures show a significant increase since logging. Predicted mean maximum April- 

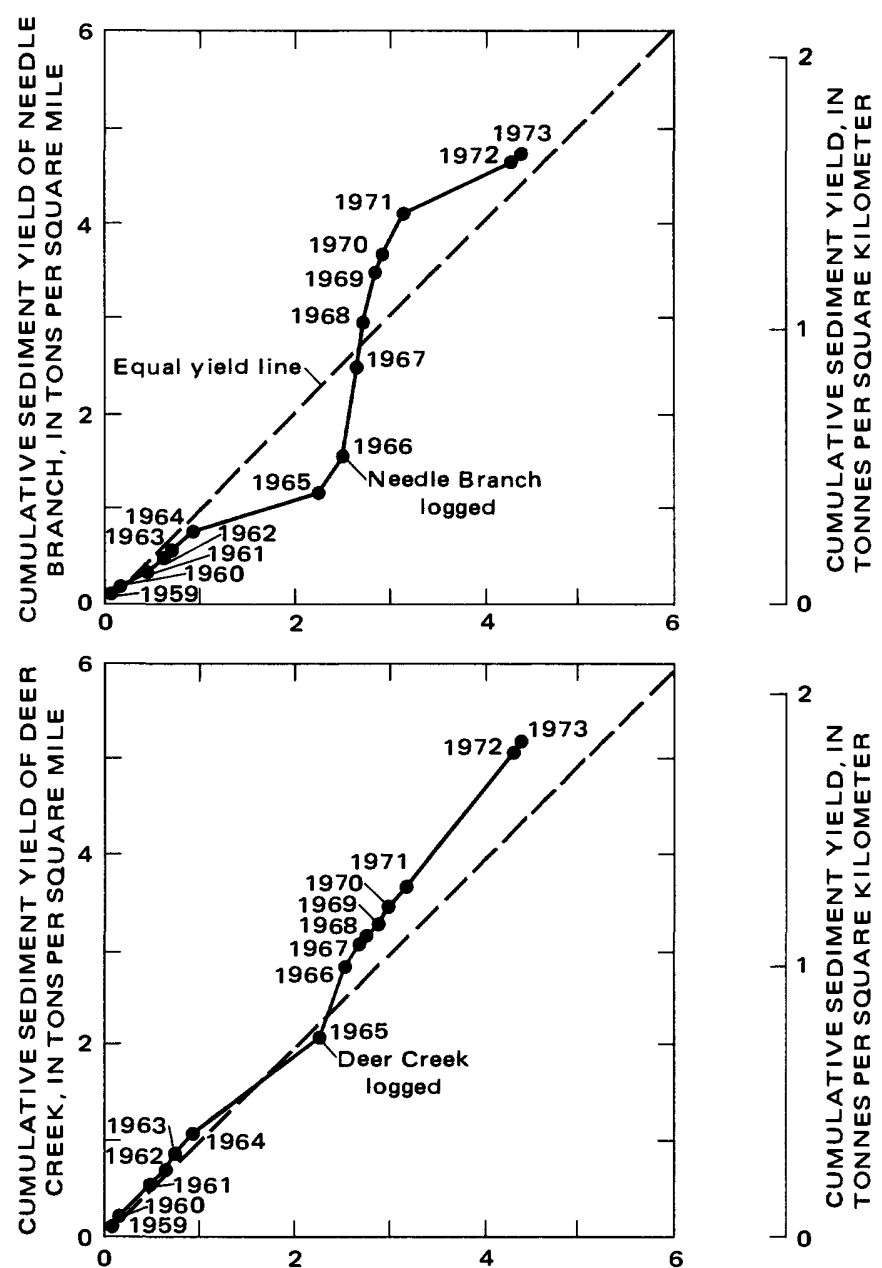

CUMULATIVE SEDIMENT YIELD OF

FLYNN CREEK, IN TONS PER SQUARE MILE

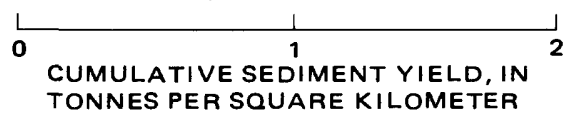

Figure 15.-Relation of cumulative annual sediment yields of Needle Branch and of Deer Creek watersheds to those of Flynn Creek watershed.

October temperature for Needle Branch was $12.0^{\circ} \mathrm{C}$ (Celsius) compared to an actual mean of $17.5^{\circ} \mathrm{C}$ after logging. It is evident from figure 16 that temperatures are returning to prelogging conditions.

Maximum monthly temperatures for Deer Creek also increased significantly after logging. Predicted mean maximum April-October 
TABLE 9.-Approximate size distribution of sediment sampled at the weirs before, during, and after logging

\begin{tabular}{|c|c|c|c|c|c|c|}
\hline \multirow[b]{2}{*}{ Stream } & \multirow[b]{2}{*}{$\begin{array}{c}\text { Number } \\
\text { of } \\
\text { samples }\end{array}$} & \multirow[b]{2}{*}{$\begin{array}{l}\text { Average of } \\
\text { flows when } \\
\text { sampled } \\
\text { ( } \mathrm{ft}^{3 / s} \text { ) }\end{array}$} & \multicolumn{4}{|c|}{ Percent } \\
\hline & & & $\begin{array}{c}\text { Clay } \\
(<0.004 \mathrm{~mm})\end{array}$ & $\begin{array}{c}\text { Silt } \\
(0.004- \\
0.062 \mathrm{~mm})\end{array}$ & $\begin{array}{c}\text { Sand } \\
(0.062- \\
2.0 \mathrm{~mm})\end{array}$ & $\begin{array}{c}\text { Very fine } \\
\text { gravel } \\
(2.0-4.0 \mathrm{~mm})\end{array}$ \\
\hline \multicolumn{7}{|l|}{ Before logging: } \\
\hline Flynn Creek & 3 & 112 & 13 & 36 & 51 & 0 \\
\hline Needle Branch & 5 & 26 & 18 & 33 & 46 & 2 \\
\hline Deer Creek & 7 & 104 & 17 & 36 & 47 & 0 \\
\hline \multicolumn{7}{|l|}{ During logging: } \\
\hline Flynn Creek & 4 & 39 & 8 & 26 & 62 & 4 \\
\hline Needle Branch & 2 & 20 & 7 & 20 & 51 & 22 \\
\hline Deer Creek & 4 & 68 & 16 & 37 & 45 & 2 \\
\hline \multicolumn{7}{|l|}{ After logging: } \\
\hline Flynn Creek & 2 & 50 & 6 & 14 & 70 & 10 \\
\hline Needle Branch & 9 & 15 & 19 & 31 & 38 & 12 \\
\hline Deer Creek & 4 & 62 & 9 & 27 & 63 & 1 \\
\hline
\end{tabular}

temperature for Deer Creek was $12.5^{\circ} \mathrm{C}$ compared to an actual mean after logging of $14.5^{\circ} \mathrm{C}$.

Monthly average minimum water temperatures in summer showed an increase immediately after logging, but after 1970 the minimum temperatures returned to prelogging conditions. Change in minimum temperatures was not evident during other seasons of the year.

\section{SUMMARY}

Changes in hydrologic characteristics after logging in Needle Branch and Deer Creek watersheds are summarized in table 11. Those changes that exceed the selected 95-percent prediction limits are considered to be statistically significant, whereas those changes within the range of prelogging experience are not considered to be significant.

For Needle Branch, after logging, increases over predicted values for annual runoff, 3-day high-flow volumes, discharge-weighted mean sediment concentrations, sediment yield, and maximum AprilOctober water temperatures all were statistically significant. During

TABLE 10.-Water temperatures, in degrees Celsius, before and after logging

\begin{tabular}{llll}
\hline \multicolumn{1}{c}{ Stream } & Maximum & Minimum & Range \\
\hline Before logging: & & & \\
Flynn Creek & 16.5 & 2 & 14.5 \\
Needle Branch & 16 & 1.5 & 14.5 \\
Deer Creek & 16 & 1 & 15 \\
After logging: & 15 & 1.5 & 13.5 \\
Flynn Creek & 26 & 1.5 & 24.5 \\
Needle Branch & & 2 & 16 \\
Deer Creek & & & \\
\hline
\end{tabular}




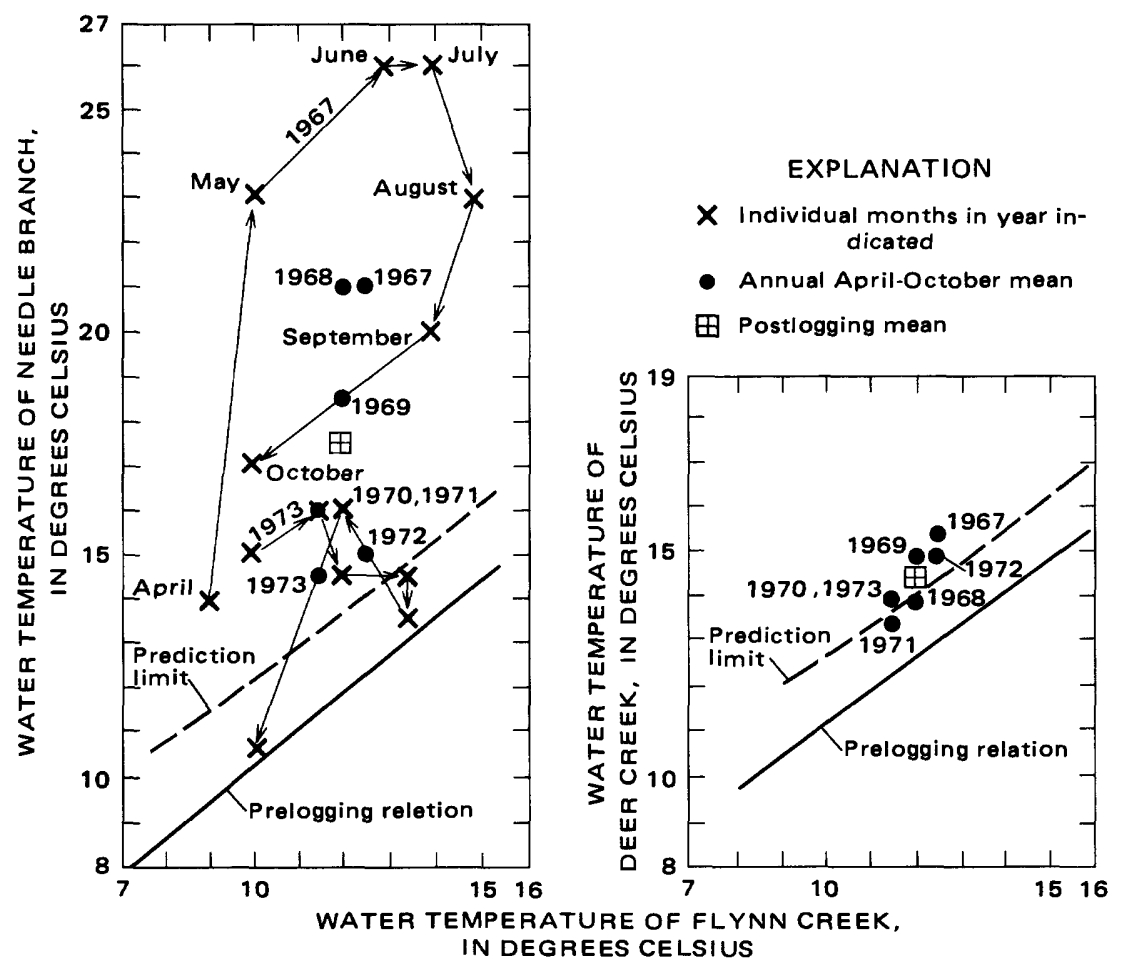

Figure 16.-Relation of maximum monthly water temperatures (April-October) of Needle Branch and of Deer Creek to those of Flynn Creek.

the last 2 years of the study, sediment concentrations and yields returned to within the prelogging prediction limits. By the end of the study (1973), water temperatures are also returning toward prelogging conditions. Peak flows increased, but not significantly. No significant changes in the mean of low flows are evident although low flows immediately after logging were higher than those before logging.

For Deer Creek, after logging, a statistically signigicant increase occurred in maximum April-October water temperatures. Annual runoff, peak flows, 3-day high-flow volumes, sediment concentrations, and sediment yields also increased over predicted values, but the increases were not statistically significant. Mean of the low flows showed a slight decrease.

The combined results seem to show that more surface water is leaving the watersheds for a given amount of precipitation after logging than before. Total runoff, peak flows, and high-flow volumes have increased. The number of low-flow days has decreased; conversely, the number of high-flow days has increased. Extreme low 


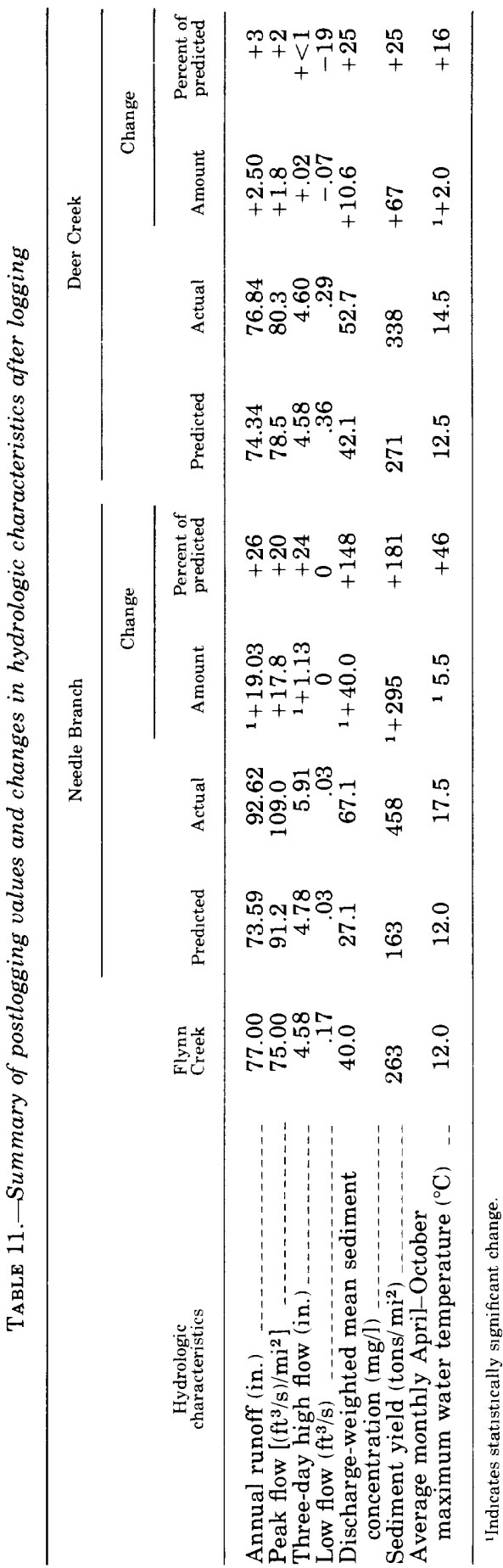


flows have stayed the same or decreased slightly. Sediment concentrations, sediment yields, and water temperatures increased greatly after clearcut logging and slightly after patch-cut logging. Six years after clearcut logging, sediment yields almost returned to prelogging conditions. Seven years after clearcutting (1973), water temperatures are approaching prelogging conditions.

\section{SELECTED REFERENCES}

Brown, G. W., and Krygier, J. T., 1971, Clear-cut logging and sediment production in the Oregon Coast Range: Water Resources Research, v. 7, no. 5, p. 1189-1198.

Dixon, W. J., and Massey, F. J., 1957, Introduction to statistical analysis: New York, McGraw-Hill Book Co., 488 p.

Ezekiel, Mordecai, and Fox, K. A., 1959, Methods of correlation and regression analysis: New York, John Wiley \& Sons, $548 \mathrm{p}$.

Harr, D. R., and Krygier, J. T., 1972, Clearcut logging and low flows in Oregon Coastal watersheds: Oregon State Univ. (Corvallis) Forest Research Lab. Research Note 54, Paper 839, 3 p.

Harris, D. D., 1973, Hydrologic changes after clearcut logging in a small Oregon coastal watershed: U.S. Geol. Survey Jour. Research, v. 1, no. 4, July-August 1972. p. 487-491.

Harris, D. D., and Williams, R. C., 1971, Streamflow, sediment-transport, and watertemperature characteristics of three small watersheds in the Alsea River basin, Oregon: U.S. Geol. Survey Circ. 642, 21 p.

Lane, E. W., 1947, Report of the Subcommittee on Sediment Terminology: Am. Geophys. Union Trans., v. 28, no. 6, p. 936-938.

Snedecor, G. W., 1956, Statistical methods [5th ed.]: Ames, Iowa State College Press, $534 \mathrm{p}$.

U.S. Geological Survey, 1960, Surface water supply of the United States, 1959, Part 14 Pacific slope basins in Oregon and lower Columbia River hasin: U.S. Geol. Survey Water-Supply Paper 1638, 300 p.

1961, Surface water supply of the United States, 1960: Part 14, Pacific slope basins in Oregon and lower Columbia River basin: U.S. Geol. Survey WaterSupply Paper $1718,305 \mathrm{p}$.

1964, Quality of surface waters of the United States, 1962: Parts 9-14, Colorado River basin to Pacific slope basins in Oregon and lower Columbia River basin: U.S. Geol. Survey Water-Supply Paper 1945, 691 p.

-1966a, Quality of surface waters of the United States, 1959; Parts 9-14, Colorado River basin to Pacific slope basins in Oregon and lower Columbia River basin: U.S. Geol. Survey Water-Supply Paper 1645, 524 p.

1966b, Quality of surface waters of the United States, 1963; Parts 9-14, Colorado River basin to Pacific slope basins in Oregon and lower Columbia River basin: U.S. Geol. Survey Water-Supply Paper 1951, 781 p.

1967, Quality of surface waters of the United States, 1961; Parts 9-14, Colorado River basin to Pacific slope basins in Oregon and lower Columbia River basin: U.S. Geol. Survey Water-Supply Paper 1885,677 p.

1968, Quality of surface waters of the United States, 1960; Parts 9-14, Colorado River basin to Pacific slope basins in Oregon and lower Columbia River basin: U.S. Geol. Survey Water-Supply Paper 1745,607 p.

1970a, Quality of surface waters of the United States, 1964; Parts 12-15, Pacific slope basins in Washington and upper Columbia River basin to Alaska: U.S. Geol. Survey Water-Supply Paper 1959, 428 p. 
1970b, Quality of surface waters of the United States, 1965; Parts 12-16, Pacific slope basins in Washington and upper Columbia River basin to Hawaii and other Pacific areas: U.S. Geol. Survey Water-Supply Paper 1966, 462 p.

-1971a, Quality of surface waters of the United States, 1966; Parts 12-16, North Pacific slope basins, Alaska, and Hawaii and other Pacific areas: U.S. Geol. Survey Water-Supply Paper 1996, $433 \mathrm{p}$.

-1971b, Surface water supply of the United States, 1961-65; Part 14, Pacific slope basins in Oregon and lower Columbia River basin: U.S. Geol. Survey WaterSupply Paper 1935, $957 \mathrm{p}$.

-1971c, Water quality records, Part 2 of Water resources data for Oregon, 1970:

Portland, Oreg., Water Resources Div., U.S. Geol. Survey, 121 p.

1972a, Quality of surface waters of the United States, 1967; Parts 12-16, North

Pacific slope basins, Alaska, and Hawaii and other Pacific areas: U.S. Geol. Survey Water-Supply Paper 2016, $431 \mathrm{p}$.

1972b, Surface water records, Part 1 of Water resources data for Oregon, 1971:

Portland, Oreg., Water Resources Div., U.S. Geol. Survey, 364 p.

-1972c, Surface water supply of the United States, 1966-70; Part 14, Pacific slope

basins in Oregon and lower Columbia basin: U.S. Geol. Survey Water-Supply

Paper 2135, $1036 \mathrm{p}$.

1972d, Water quality records, Part 2 of Water resources data for Oregon, 1971:

Portland, Oreg., Water Resources Div., U.S. Geol. Survey, 123 p.

1973a, Quality of surface waters of the United States, 1968; Parts 12-16, North

Pacific slope basins, Alaska, Hawaii, and other Pacific areas: U.S. Geol. Survey

Water-Supply Paper 2100, 464 p.

1973b, Surface water records, Part 1 of Water resources data for Oregon, 1972:

Portland, Oreg., Water Resources Div., U.S. Geol. Survey, 378 p.

$-1973 c$, Water quality records, Part 2 of Water resources data for Oregon, 1972:

Portland, Oreg., Water Resources Div., U.S. Geol. Survey, 137 p.

-1974a, Quality of surface waters of the United States, 1969; Parts 12-16, North

Pacific slope basins, Alaska, Hawaii, and other Pacific areas: U.S. Geological Survey Water-Supply Paper 2150, $480 \mathrm{p}$.

1974b, Surface water records, Part 1 of Water resources data for Oregon, 1973:

Portland, Oreg., Water Resources Div., U.S. Geol. Survey, 409 p.

$-1974 c$, Water quality records, Part 2 of Water resources data for Oregon, 1973:

Portland, Oreg., Water Resources Div., U.S. Geol. Survey, 153 p.

U.S. Inter-Agency Committee on Water Resources, 1957a, The development and calibration of visual accumulation tube, Report 11 of A study of methods used in measurement and analysis of sediment loads in streams: Minneapolis, Minn., St. Anthony Falls Hydraulic Lab., 109 p.

$1957 \mathrm{~b}$, Some fundamentals of particle-size analysis, Report 12 of A study of methods used in measurement and analysis of sediment loads in streams: Washington, U.S. Govt. Printing Office, 55 p.

1959, Federal inter-agency sedimentation instruments and reports, Report AA of A study of methods used in measurement and analysis of sediment loads in streams: Minneapolis, Minn., St. Anthony Falls Hydraulic Lab., 41 p.

1961, The single stage sampler for suspended sediment, Report 13 of A study of methods used in measurement and analysis of sediment loads in streams: Washington, U.S. Govt. Printing Office, 105 p.

1963, Determinations of fluvial sediment discharge, Report 14 of A study of methods used in measurement and analysis of sediment loads in streams: Washington, U.S. Govt. Printing Office, 151 p.

Williams, R. C., 1964, Sedimentation in three small forested drainage basins, Oregon: U.S. Geol. Survey Circ. 490, 16 p. 